\title{
The Migration Pathway of the Proto Nuclear Micronesians: A linguistic Trail
}

\author{
Jae Jung Song * \\ (University of Otago, New Zealand)
}

\begin{abstract}
Over the last five decades or so, historical linguists have proposed as many as four different hypotheses concerning the migration pathway of Proto Nuclear Micronesians (i.e. the ancestors of Nuclear-Micronesian-language speakers): Proto Nuclear Micronesians may have reached Micronesia by moving from northern Vanuatu, from the Cristobal-Malaitan region, from the Admiralty or the St Matthias Islands, or even from somewhere in the vast southeast Solomons-New Hebrides region. This article provides an overview of these hypotheses, coming to the conclusion that there is no conclusive linguistic evidence, historical-comparative or otherwise, for any of the hypotheses. In view of this state of affairs, the article makes use of Johanna Nichols's population typology model so as to understand better the migration route of Proto Nuclear Micronesians. This innovative model has been developed to investigate geographical distributions of structural properties with a view to making inferences about human migration. In particular, the structural property of possessive classifiers, which is one of the major structural characteristics of Micronesian languages, is selected in order to ascertain how this structural property is distributed in the wider geographical areas surrounding Micronesia. Proto Nuclear Micronesians must have carried their propensity for a large number of possessive classifiers in their language(s) when travelling from somewhere into Micronesia. There is a distinct possibility that whomever Proto Nuclear Micronesians interacted linguistically (as well as culturally and genetically) with must have shared the same structural propensity. By interpreting the geographical cline of possessive classifiers from the higher to lower end (i.e. the largest to the lowest number of possessive classifiers), it will be possible to trace the migration pathway of Proto Nuclear Micronesians back to their immediate homeland. This population-typology exercise points to the Santa Cruz Islands, via northern Vanuatu, as the place from which Proto Nuclear Micronesians entered
\end{abstract}

\footnotetext{
* Jae Jung Song: Linguistics Programme, University of Otago, PO Box 56, Dunedin, New Zealand. E-mail: jaejung.song@stonebow.otago.ac.nz. 
Micronesia. The article also evaluates evidence arising from archaeology and genetics, which also seems to support the proposed pathway of Proto Nuclear Micronesians.

Keywords: archaeology, genetics, historical linguistics, migration pathway, population typology, possessive classifiers, Proto Nuclear Micronesians

\section{Introduction}

There are a number of disciplines which have shed light on Proto Nuclear Micronesians' migration route(s) to Micronesia. For instance, thanks to advances made in Micronesian archaeology in the last two decades or so, much has been added to our understanding of human migration into central and eastern Micronesia (i.e. Micronesia excluding the Mariana Islands, Yap and Palau). The once widespread notion that Micronesia, with many coral atolls, but few volcanic islands, might prove to be unrewarding for archaeological research has completely been dispelled by recent discovery of pottery, and other material cultural artefacts (e.g. Alkire 1977, Takayama 1981, Davidson 1988, Athens 1984, 1990a, 1990b, 1995, Ayres 1990, Intoh 1996, 1997). Moreover, Howells's (1973) so-called Micronesian route theory of Polynesian migration (or Buck's (1938) suggestion to that effect) has proven untenable by means of Lapita-based archaeological evidence alone (e.g. Craib 1983: 922; also Bellwood 1989: 44).

More recently, genetic studies have also played an increasingly important role in analysis of population affinities and also in the reconstruction of human migration in the Pacific (e.g. Flint et al. 1986, Hill and Serjeantson 1989, and O'Shaughnessy et al. 1990, Clark and Kelly 1993, Melton et al. 1998 among others). By tracing trails of genetic markers through the Pacific, geneticists have been able to reconstruct migration routes of various populations with a great deal of confidence. For example, evidence from research on HLA (human leucocyte antigen) genes and antigens, e.g. Serjeantson et al. (1983), and Serjeantson (1989), militates against the Micronesian route theory of Polynesian migration, notwithstanding anthropomorphic similarities between the two populations previously observed by Howells (1973). Undoubtedly, genetics will continue to make important contributions to our understanding of population movements in the Pacific, and, needless to say, elsewhere in the world.

Even before archaeologists and geneticists began to carry out their work, linguists had written about the migration route(s) of Proto Nuclear Micronesians, based on linguistic data alone. Thus, as early as in 1955 Grace claimed that languages of Micronesia - with the exception of Palauan and Chamorro - have their closest linguistic affiliations with those of the New Hebrides (now Vanuatu) (also see Grace 1961, and 1964). Moreover, he 
interpreted this to be an indication of "a [human] movement from the New Hebrides to Micronesian [sic]"(1964: 367). ${ }^{1}$ Other linguists seem to concur with this view. For instance, Pawley and Green (1973), and also Tryon (1984) reinforce Grace's suggestion: Proto Nuclear Micronesians reached Micronesia by moving north from northern/central Vanuatu.

The linguistic evidence in support of the view put forward originally by Grace comes from Shutler and Marck's work (1975), which is in turn based on Marck's (n.d.) 100 word-lexicostatistical comparison of seven Nuclear Micronesian languages and three "Eastern Oceanic" languages (cf. Marck 1975). However, although Shutler and Marck (1975) make a very laudable attempt to bring archaeology and linguistics together, their linguistic evidence is not historical-comparative one built on regular sound correspondences but only lexicostatistically based (but cf. Pawley 1972, 1977; for brief discussion of the superiority of the historical-comparative method over the lexicostatistical method and of fundamental problems with the latter in historical reconstruction, see Blust 1995: 455-459). Moreover, the number of the "Eastern Oceanic" languages included in Shutler and Marck's comparison is so small that it may be injudicious to draw firm conclusions or inferences from their work. Nonetheless, it seems that Shutler and Marck's (1975) hypothesis has been widely accepted or presented by archaeologists - with the exception of Bellwood (1989: 28), and Spriggs (1995: 121) — as if it were the received view in linguistics. For instance, Intoh (1997), Athens (1990, 1995), Davidson (1988), Ayres and Mauricio (1987), and Craib (1983) all make explicit reference to Shutler and Marck's (1975) scenario concerning the migration pathway of Proto Nuclear Micronesians. These archaeologists, however, also tend to speak of a much wider region as the homeland of Proto Nuclear Micronesians than the linguists: eastern Melanesia (including not only Vanuatu, but also the southeast Solomons). For example, Athens (1990a) makes an attempt to trace the pottery sherds that he discovered at the Nan Madol site on Pohnpei to the late Lapita Plain Ware tradition in the southeast Solomons and Vanuatu. He then claims that these areas have also been suggested by linguistic data (1990a: 29), i.e. Shutler and Marck (1975), as the homeland of Proto Nuclear Micronesians. As has been noted, however, it is only the northern Vanuatu that has been identified by Shutler and Marck (1975), and other linguists as the area from which Micronesia was colonised.

Geneticists (e.g. O'Shaughnessy et al. 1990) seem to believe linguists to be of the view that Proto Nuclear Micronesians may have derived from northern island Melanesia. Thus, O'Shaughnessy et al. (1990: 145) point to Pawley and Green (1984), and Tryon (1984) -

\footnotetext{
(1) In what follows, Micronesia only refers to central and eastern Micronesia excluding western Micronesia (i.e. Yap, Palau, and the Mariana Islands).
} 
the latter itself based directly on Shutler and Marck (1975) — among others as the source of this information. But, again, it is only the northern/central Vanuatu, not northern island Melanesia as a whole, that has been put forward by Tryon (1984), for instance, as the immediate homeland of Proto Nuclear Micronesians.

It is remarkable that Shutler and Marck's (1975) hypothesis has been accepted not only by archaeologists but also by geneticists as the received view in Oceanic linguistics, when there actually are as many as three linguistic subgrouping hypotheses concerning Nuclear Micronesian, namely Blust (1984), Pawley $(1972,1977)$, and Smythe (1970). There indeed is no agreement among Oceanic linguists as to which of these three is correct. The subgrouping hypotheses in turn give rise to three or four Micronesian migration scenarios.

First, based on his lexical comparisons of Nuclear Micronesian languages, and Cristobal-Malaitan languages in the Solomon Islands chain, Blust (1984) arrives at the subgrouping hypothesis which subsumes these two groups of languages (but cf. Pawley's (1972) subgrouping of Cristobal-Malaitan and Guadalcanal-Nggelic languages). "[T]he argument that the [Cristobal-Malaitan] and [Nuclear Micronesian] languages have experienced a period of common development" (Blust 1984: 132) in turn gives rise to a scenario of population movement from the Cristobal-Malaitan region into Micronesia. There currently is a lack of archaeological evidence in support of this scenario, however. No Lapita sites have yet been discovered in the Solomon Islands chain west of the Santa Cruz Islands (Green 1979: 51, Spriggs 1995: 113, Kirch 1997: 53), although this may be due possibly to post-depositional geomorphic changes and also to lack of archaeological survey (Spriggs 1984: 211).

By contrast, Smythe (1970) points to a possible connection between languages of Micronesia and those of the Admiralty Islands (i.e. Manus Island), based largely on their lexical similarities. He thus speaks of "Micronesian infiltration" into the Admiralty Islands (1970: 1221). If this infiltration is understood to have been more than (sustained) contact between the two, i.e. migration, the possibility of Proto Nuclear Micronesians having moved south to the Admiralty Islands for settlement can easily be entertained. There is archaeological evidence against this scenario, however. According to Pawley and Green (1984: 140; also Green 1981), there is a "probable case [which] involves early pottery assemblages in the Admiralty Islands which exhibits a continuity of the tradition that extends back to nearly 1700BC, and [which] includes some levels with a few Lapita sherds of only slightly later date". In Micronesia (i.e. Pohnpei, Truk and Kosrae), on the other hand, the pottery tradition - i.e. distinct from the one derived from Yap, Palau, or the Marianas (e.g. Takayama 1981, Bellwood 1989: 44-45) — is much later than that of the Admiralty Islands, and probably is related to the late Lapita Plain Ware pottery tradition, which is thought to have begun only after $500 \mathrm{BC}$ in the southeast Solomons and Vanuatu 


\section{Jae Jung Song}

(Athens 1990a: 29; also see Green 1979: 45). This temporal priority of the pottery of the Admiralty Islands over that of Micronesia suggests that Micronesia was settled much later than the Admiralty Islands. In point of fact, "[t]he colonization of the [Admiralty Islands] ... appears to have occurred several hundred years prior to the Lapita dispersal" (Spriggs 1984: 206; also Kennedy 1982). Nor should one lose sight of the Admiralty Islands as a major source of obsidian for nearby areas (Ambrose et al. 1981; also see Bellwood 1989: 39, Best 1987, Ayres and Mauricio 1987, and Spriggs 1997: 128, 150). For instance, some of the obsidians recovered from Manus Island have been dated to around 3450 BP (Ambrose et al. 1981: 14). Thus, if there was human migration between Micronesia and the Admiralty Islands, it is more likely to have been from the latter to the former than the converse.

In conjunction with the above archaeological evidence, however, Smythe's (1970) subgrouping hypothesis may lead to the opposite possibility that both Nuclear Micronesian and Admiralties languages had a common period of development in the Admiralty Islands, and that speakers of what later became Nuclear Micronesian languages entered Micronesia directly from the Admiralty Islands. A third possibility is entertained by Ross (1988: 326) that Micronesia and the Admiralty Islands may each have been settled by migrants from Mussau Island (i.e. the St Matthias Islands). ${ }^{(1)}$ Thus, either the Admiralty Islands or the St Matthias Islands may be a possible candidate for the homeland of Proto Nuclear Micronesians. Both Jackson (1986: 226) and Ross (1988: 326) indeed emphasise that Smythe's (1970) subgrouping hypothesis is deserving of further investigation, especially in the absence of published data on languages of the Admiralty Islands. As non-linguistic evidence in support, Jackson (1986: 226) points to the geographical propinquity, and also certain technological similarities (e.g. gardening techniques, and the appearance of canoes) (cf. Chowning 1977) between Micronesia and the Admiralty Islands.

Finally, Pawley (1972) proposes what he calls North Hebridean-Central Pacific, a linguistic grouping which includes Fijian, Polynesian, and languages of the Banks, Torres, and northern New Hebrides Islands. He believes that there is some evidence for including Gilbertese, a Nuclear Micronesian language, in North Hebridean-Central Pacific. By

\footnotetext{
(1) The present writer is not aware of any archaeological evidence in support of Ross's (1986) suggestion. As a matter of fact, there seems to be some evidence for material cultural artefacts imported into Mussau Island from other places including the Admiralty Islands (Kirch 1997: 145, 242-246, Spriggs 1997: 113). Between Mussau Island and Micronesia, on the other hand, the former was settled much earlier than the latter, as evidenced by the "obsidians [...] from excavations of a Lapita pottery complex [on Eloaue in the St Matthias Islands], which elsewhere have been radiocarbon dated to around 3000 years ago" (Ambrose 1981: 14; also see Ayres and Mauricio 1987). This date certainly is prior to the onset of Micronesian colonisation (i.e. 2000 BP, e.g. Intoh 1997: 20; but cf. Rehg 1995). This may at least preclude migration from Micronesia to Mussau Island.
} 
extension, other Nuclear Micronesian languages should also belong to this grouping (Pawley 1972: 134). The position of Nuclear Micronesian within North Hebridean-Central Pacific remains unchanged in Pawley (1977), although the term "Eastern Oceanic" is redefined to refer strictly to his earlier North Hebridean-Central Pacific (Jackson 1986: 215). Regardless of the validity of the Eastern Oceanic subgroup (cf. Pawley 1981: 277, 301, and also Pawley and Ross 1993: 440, who now believe that evidence for this subgroup is unconvincing), inclusion of Nuclear Micronesian languages in such a large subgroup does not make it easy to pinpoint any specific area as the homeland of Proto Nuclear Micronesians. Indeed, Pawley (1972: 140-141) indicates merely that the location of the Eastern Oceanic homeland may be somewhere in the southeast Solomons-New Hebrides region, because that is where the centre of diversity in Eastern Oceanic lies. From this, it also follows that Proto Nuclear Micronesians may also have migrated from somewhere in the vast southeast Solomons-New Hebrides region.

Based on linguistic data alone, then, it is possible to propose at least three or four candidates for the homeland of Proto Nuclear Micronesians. First, Proto Nuclear Micronesians travelled north from the (northern) Vanuatu region into Micronesia for settlement. This is basically the scenario put forward by Shutler and Marck (1975) and possibly also by Pawley $(1972,1977) .{ }^{11}$ The second possibility is that Proto Nuclear Micronesians entered Micronesia from the Cristobal-Malaitan region of the main Solomon Islands chain. This is Blust's view (1984). Based loosely on Smythe's hypothesis (1970) it can also be suggested that Proto Nuclear Micronesians migrated from the Admiralty Islands to Micronesia. Finally, the migration pathway from the St Matthias Islands to Micronesia arises directly from Ross (1988: 326).

\section{The linguistic position of Nuclear Micronesian within Oceanic}

In the present section, linguistic evidence which the foregoing migration scenarios draw upon will briefly be discussed in order to highlight the fact that there indeed is no consensus among linguists as to the linguistic position of Nuclear Micronesian within Oceanic. This will be based mainly on Jackson's (1986) review of Smythe (1970), Pawley (1972), and Blust (1984). There is also the need to draw attention to the dearth of linguistic data which can help decide between these competing hypotheses and related migration scenarios. No new historical-comparative data seem to be forthcoming, and may actually

\footnotetext{
(1) Although Pawley (1972) identifies the larger southeast Solomons-New Hebrides region as the homeland of Proto Eastern Oceanic speakers, he recognises a closer linguistic affinity between Nuclear Micronesian and North Hebridean (see 2.1). Thus, Pawley (1972) may not be very different from Shutler and Marck (1975) insofar as the location of Proto Nuclear Micronesian homeland is concerned.
} 
be hard to come by. In fact, Jackson (1986) was the last published historical-comparative work that had dealt with the external relationships of Nuclear Micronesian languages.

\subsection{Pawley $(1972,1977)$ : Proto Nuclear Micronesian and North Hebridean}

Pawley $(1972,1977)$ proposes that Nuclear Micronesian languages may form a large subgroup not only with languages of the Banks, Torres, and northern New Hebrides Islands, but also with Fijian and Polynesian. This subgroup is referred to by Pawley as Eastern Oceanic or North Hebridean-Central Pacific. He (1977) offers as many as ten properties in support of Eastern Oceanic. Jackson (1986: 220-221), however, has demonstrated that most of these are (i) merely retentions also reflected in non-Eastern Oceanic or non-Oceanic Austronesian languages, (ii) unattested in Nuclear Micronesian languages or (iii) encumbered with "too many irregularities to be considered as subgrouping evidence."

There, however, is one piece of evidence put forth by Pawley (1977) which Jackson (1986: 215-220) dwells upon at great length: loss of Proto Oceanic (POc) * R or its merger with POc *d. Four of the twelve lexical items examined by Jackson - POc *RuNma 'house', POc *qapaRa 'shoulder', POc *maRaqan 'light in weight', and POc *wakaR(i) 'root' - do exhibit an exact parallel between Proto Nuclear Micronesian and New Hebridean in terms of loss of $* \mathrm{R}$ or its merger with $* \mathrm{~d}$, thereby providing support for the subgrouping of these two groups. (Note that Jackson only deals with New Hebridean, because Pawley finds little evidence for linking Nuclear Micronesian with the Central Pacific branch of Eastern Oceanic.) This parallelism also suggests that $* \mathrm{R}$ was either lost or merged with $* \mathrm{~d}$ in individual lexical items in New Hebridean and Proto Nuclear Micronesian, although these lexical items themselves do not allow one to identify any specific dialect group in the New Hebrides from which Proto Nuclear Micronesian separated (Jackson 1986: 218).

However, when some of the other lexical items are scrutinised, there is "extremely contradictory" evidence to the effect that the Banks Islands emerge not only as a New Hebridean area from which Proto Nuclear Micronesian may have derived, but also as an area from which Proto Nuclear Micronesian could not have derived! Moreover, there is counterevidence based on the reflexes of POc *meRa 'red' in Proto Nuclear Micronesian and New Hebridean, whereby it is indicated that $* \mathrm{R}$ must have been a distinct phoneme in Proto Nuclear Micronesian at the time of its separation from New Hebridean (and later merged with $* \mathrm{~d}$ ), and that $* \mathrm{R}$ must have been lost in New Hebridean subsequent to that separation.

This conundrum notwithstanding, Jackson (1986: 220) accepts the possibility that loss of $* \mathrm{R}$ and its merger with $* \mathrm{~d}$ may have occurred in an ancestral language of both Proto Nuclear Micronesian and New Hebridean, although he is quick to qualify this by saying that the whole thing can be "entirely coincidental". Nonetheless, the parallelism in the four 
lexical items is strong enough to lead him (1986: 220) to conclude that the Micronesian and New Hebridean reflexes of $* \mathrm{R}$ do not contradict the possibility that the two language groups subgroup together.

\subsection{Blust (1984): Nuclear Micronesian and Cristobal-Malaitan}

Blust (1984) puts forward a subgrouping hypothesis which links Nuclear Micronesian directly with languages of the Cristobal-Malaitan region. This subgroup is referred to by Blust (1984) as Malaita-Micronesian. "The absence of clear phonological or syntactic innovations shared exclusively by the Nuclear Micronesian and Cristobal-Malaitan languages" (Blust 1984: 101-102) leads him to draw heavily upon lexical data, which comprise putative lexical, morphological and semantic innovations. There are twenty eight such innovations discussed in Blust's (1984) work. As Blust (1984: 132) himself acknowledges, however, the evidence arising from these innovations "is limited". Nonetheless, he is firmly of the view that at least four of these innovations present a very strong case for his Malaita-Micronesian subgrouping hypothesis (Blust 1984: 132).

Jackson (1986: 221-225), on the other hand, does not share Blust's (1984) optimism. For instance, Blust's "Proto Malaita-Micronesian" *pwaRusu 'nose' is attested outside the putative subgrouping, e.g. in Yapese. Jackson (1986: 222) also makes reference to New Hebridean languages which seem to suggest that *pwaRusu was actually a compound made of two elements *pwa- and *Ru(n)su (both with meanings related to 'nose'), which may perhaps have been present as far back as in POc. Thus, there is every likelihood of *pwaRusu having been a mere retention in Micronesian and Cristobal-Malaitan, or having developed independently in the two groups, based on the two separate POc elements, *pwa- and *Ru(n)su. Similarly, the lexical innovation *masawa 'sea' is thought to have been "a continuation of an earlier form" (Jackson 1986: 223). The problem with the other lexical innovation *maNo 'breath, to breather, fontanelle' is, as Jackson (1986: 223-224) explains, that there is too much inconsistency in meaning between Micronesian and Cristobal-Malaitan. This leads him to the view that the innovation in question is a very tenuous one. The semantic innovation that Blust (1984: 117) thinks provides "a particularly compelling piece of evidence" for his Malaita-Micronesian subgroup comes from "Proto Malaita-Micronesian" *lama 'lake, lagoon' $(<\mathrm{POc} *$ laman 'sea beyond the reef, deep blue sea'). Jackson (1986: 224) points out, however, that Arosi, Marshallese, and Saipan Carolinian reflexes "appear to continue the POc reference to deep water (albeit water which is relatively close to shore)." Thus, he is of the opinion that *lama may independently have undergone the same semantic change in both Micronesian and Cristobal-Malaitan.

Jackson (1986: 225) concludes that Blust's (1984) Malaita-Micronesian subgroup is in need of conclusive evidence, because "the innovative status of these forms [i.e. "Proto 
Malaita-Micronesian" *pwaRusu, *masawa, *maNo, and *lama] is not as certain as Blust believes." With Blust's strongest evidence for his proposed subgrouping called into question, Jackson's circumspection seems to be well placed.

\subsection{Smythe (1970): Nuclear Micronesian and the Admiralty Islands}

Smythe (1970) develops the idea of linking Nuclear Micronesian with languages of the Admiralty Islands, based on lexical and grammatical similarities between the two. Blust (1984: 129), however, dismisses Smythe's view because it "rests on virtually no solid evidence of exclusively shared lexical innovation." Blust goes on to claim that, being of a general typological character, the few grammatical features that Smythe adduces in support also fail to uphold the Nuclear Micronesian-Admiralties hypothesis. Contrary to Blust's negative view, Jackson (1986: 225-226) argues that some of Smythe's lexical comparisons may collectively present a case for further investigation, although they may individually be problematic. As has been noted in the Introduction, Jackson (1986: 226) also points to "non-linguistic evidence for a connection between" Nuclear Micronesian and Admiralties languages, namely the close geographical proximity and technological similarities. In view of the nature of Smythe's linguistic evidence, however, it comes as no surprise that Jackson (1986) only speaks of a connection between the two language groups. The connection is not strong enough to warrant discussion of a linguistic relationship between them, as in the case of Pawley's Eastern Oceanic and Blust's Malaita-Micronesian. It may thus well be due only to sustained contact.

\subsection{Summary}

The unavoidable conclusion to be drawn from the preceding discussion is that there is no conclusive linguistic evidence in support of Nuclear Micronesian subgrouping with languages of the New Hebrides, of the Cristobal-Malaitan region, or of the Admiralty Islands. Probably the strongest of the three candidates is the New Hebrides, and the weakest the Admiralty Islands. Proto Nuclear Micronesian may thus have derived from languages of the northern New Hebrides or of the Cristobal-Malaitan region. This in turn suggests that Proto Nuclear Micronesians may have come either from the northern Vanuatu or from the Cristobal-Malaitan region. Unfortunately, there has been no historical-comparative work on the external relationships of Nuclear Micronesian since Jackson (1986). It remains to be seen whether or not the absence of new research on Micronesian historical-comparative linguistics may be an indication that historical-comparative linguistics has said all that it can possibly say about the external relationships of Nuclear Micronesian languages (and about the migration route(s) of Proto Nuclear Micronesians). (Hopefully not!) This lack of new historical-comparative evidence, however, calls for the need to ascertain whether or not there may be linguistic data, other than historical-comparative or lexicostatistical, which can be utilised to understand the 
migration pathway(s) of Proto Nuclear Micronesians. Indeed, the main objective of the present paper is to argue for the existence of such linguistic evidence, and to expatiate upon it, albeit in an exploratory manner.

\section{Geographical distribution of typological markers: linguistic trails}

Nichols (1992) has demonstrated in a most ingenious way the validity of linguistic typology in population migration research. ${ }^{\mathbb{1}}$ This kind of linguistic typology is referred to aptly by Nichols as "population typology". The main objective of population typology is to discover "principles governing the [geographical or areal] distribution of structural [i.e. typological] features among the world's languages" with a view to making inferences about human migration, and spread of languages, and thus to contributing to our understanding of linguistic prehistory (Nichols 1992: 2). Population typology diverges from the comparative method in that it deals with neither individual languages nor individual etyma but rather with populations of languages, and geographical distributions of structural features and types (Nichols 1992: 280).

The interpretive model which Nichols (1992: 213-215) favours in an attempt to take account of her data is based on population genetics, wherein it is understood that one of the factors driving evolution is the tendency of genes to reach equilibrium in populations. How this actually happens is dependent crucially on two variables: (i) size of populations; and (ii) initial frequencies. The smaller the population, the sooner frequencies stabilise at $100 \%$ or $0 \%$; and $100 \%$ for high initial frequencies or $0 \%$ for low initial frequencies. The skewing of a typological feature in the initial population of languages is postulated, for example, with less than half of the western languages with the feature, and more than half of the eastern languages with the feature. Then, just like biological genes, the skewing of frequencies has over time played out on an increasingly larger and larger scale, while stabilising at $0 \%$ or $100 \%$ at the extreme periphery.

Inclusive/exclusive oppositions in first-person pronouns have been identified as one such typological feature. The geographical distribution of these pronouns "increases from area to area on a cline from west to east, and [also] with a clear distinction between Old World and colonized areas", with the extreme peripheral areas of Europe and (northern) Australia

\footnotetext{
(1) As the reader recalls, Blust (1984: 129) takes a dim view of use of typological properties in subgrouping, to which typological evidence is "of little relevance". This may indeed also be the not uncommon perception of linguistic typology within historical linguistics. Thus, it may not be incorrect to say that some historical linguists (e.g. Haider 1985) will endorse Blust's pessimistic view without reservation, notwithstanding other linguists' efforts in demonstrating otherwise (e.g. Greenberg 1957, 1995, Jakobson 1958, Hawkins 1979, 1983, and Comrie 1993 among others). However, it is outside the purview of the present paper to evaluate the two opposing positions on the role of linguistic typology in historical linguistics (but see Song 2001: 298-317).
} 


\section{Jae Jung Song}

ending up with a zero frequency and a 100\% frequency, respectively (Nichols 1992: 185, 196-198, 278). This global west-to-east cline, with a substantial difference between the Old World and the colonised areas in particular, is manifested by the respective percentages of languages having the distinction in question in the three macroareas, i.e. Old World, New World, and Pacific. Exactly the same cline is observed also within each and every one of the three macroareas. What is so remarkable about this global west-to-east cline is that it mirrors the directionality or the vector of human migration itself, as is currently understood. The present paper draws its inspiration from this particular aspect of Nichols's pioneering work by making an attempt to interpret the geographical cline of the intensity - rather than frequency as in Nichols (1992) — of one typological property as reflecting the vector of Proto Nuclear Micronesian migration.

Determining the geographical distribution of properties is nothing new to genetics-based research on population migration. Genetic markers linked with specific human populations have been utilised in an attempt to reconstruct their migration pathways, and also to locate their homelands, (e.g. Flint et al. 1986, Hill and Serjeantson 1989, and O'Shaughnessy et al. 1990, Clark and Kelly 1993, and Melton et al. 1998). This is possible because human populations, while interbreeding, contribute their genes to each other's gene pools. Different populations may have different unique genetic markers. By plotting genetic trails through populations, geneticists are able to make inferences about population migration.

Typological properties (or structural features) can likewise be plotted or traced over geographical areas, because they leave trails through populations of languages just as genetic markers leave trails through human populations. To give a simple hypothetical situation, suppose some of the languages indigenous to an area migrate into an uninhabited area, with other languages remaining in the old area. From this new area some languages continue to move into another uninhabited area, with other languages staying behind, and so on. Typological properties of the initial population of languages will then also be carried around by migrant languages. In other words, migrant languages will leave a trail of typological properties behind them. Far more frequently than not, languages migrate into already inhabited areas. Suppose some of the languages indigenous to an area move into an inhabited area while others, as in the case of the first situation, remain in the old area, and so on. Furthermore, migrant languages come in contact with pre-existing languages of the new area. The latter may then acquire typological properties from the former. (The converse also is equally possible.) From this new area, some languages continue to move into another inhabited area, thereby yet again coming in contact with pre-existing languages. The latter's acquisition of typological properties from the former again takes place. The whole process may repeat itself over and over again. In this less simple hypothetical situation as well, migrant languages will leave a trail of typological properties 
behind them by opting to stay behind and/or by donating typological properties to pre-existing languages. By tracing such linguistic trails, it may be possible to draw inferences about population migration. Note that linguistic trails may inevitably cut across linguistic affiliations (i.e. linguistic subgroupings). This, however, is not unexpected because typological properties can be borrowed from one linguistic group into another. Inferences to be drawn from linguistic trails do not concern linguistic subgrouping, but population migration.

It is quite possible, of course, that (nearby) areas where migrant languages have missed may by chance also contain languages with the same typological properties. In this case, there is much likelihood that these areas may incorrectly be included in the linguistic trail. Needless to say, inferences or conclusions drawn from such a 'false' linguistic trail are unlikely to provide an accurate reconstruction of population migration. However, linguistic trails are not merely geographically continuous lines of areas. Areas located on a 'genuine' linguistic trail may also vary from one another, with a given typological property increasing or decreasing in intensity (e.g. more or less complexity of the property) or in frequency (e.g. more or fewer languages with the property) from one end of the trail to the other. In other words, linguistic trails may constitute geographical clines of typological properties (cf. Nichols 1992). This may need explanation. Suppose languages spoken in one area initially all have one and the same typological property, but some of them have additionally developed a propensity for expanding the property (i.e. high intensity), whereas others lack that propensity (i.e. low intensity). In other words, there is a disparity in intensity in the initial population of languages. When some of the languages migrate into a new area, the original disparity in intensity may also be carried from the old area to the new. The disparity, however, will now be displayed on a larger scale, that is, over the combined old and new areas. (The geographical scale will increase in proportion to the number of newly colonised areas.) The original disparity will thus play out on an increasingly larger and larger scale as languages spread over time, although it will remain to be evident in each of the areas involved, albeit to varying degrees. The direct consequence of this is that the range of intensity will be different between the old and new areas to the effect that, for instance, the maximum level of intensity found in the new area may be higher than that found in the old area. ${ }^{(1)}$ Thus, the initial disparity in the old area is manifested or 'replicated' by the disparity in the range of intensity between the old and the new area themselves, i.e. the old and the new area occupying the lower and the higher end

\footnotetext{
(1) It can work the other way around, the old area being the higher end of the intensity scale and the new area being the lower end of the scale. In this case, the property is 'dying out' as one moves further from the origin of dispersal.
} 
of the intensity scale, respectively, as it were. This is schematised in Figure 1. The old area (or the left oval in Figure 1) exhibits a range of intensity from 1 to 3. (The higher the number, the greater the intensity.) The range of intensity in the first new area (or the middle oval) is from 2 to 5 , and that in the second or last new area (or the right oval) from 4 to 8 . The initial disparity in intensity in the old area is defined by the range of intensity in that area, i.e from 1 to 3 . This initial range of intensity then contrasts with the range of intensity in the first new area, i.e. from 2 to 5 . In other words, the disparity in intensity in the combined old and first new area is between the range of intensity in the old area (i.e. 1 to 3) and that in the first new area (i.e. 2 to 5). Also note that the maximum level of intensity of the middle oval (i.e. 5) is greater than that of the left oval (i.e. 3); the maximum level of intensity of the right oval (i.e. 8) is greater than that of the middle oval. This is not unexpected, because, in order to play out the initial disparity on an increasingly larger and larger scale, the maximum level of intensity in new areas will become higher than that in old areas (cf. Nichols 1992). (In fact, one consequence of this may well be maximal stabilisation of intensity at one extreme periphery of the geographical cline.) Thus, by moving from the higher end of the geographical cline to the lower end (as in Figure 1), it may be possible to make inferences about population migration itself.

FIGURE 1: GEOGRAPHICAL CLINE OF INTENSITY

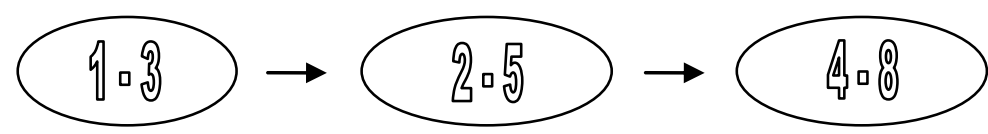

N.B. The higher the number the greater the intensity of the typological marker. Each of the ovals represents a geographical area. $\downarrow=$ direction of migration

The preceding discussion suggests that an area which fails to fit in with a gradual geographical cline of intensity (e.g. by displaying a markedly different range of intensity) may not belong properly to the linguistic trail, even though it contains languages with the typological property in question. Such an area may have to be excluded from the linguistic trail, because languages in the area may always have had the property without having borrowed it from migrant languages. At best, the area may need to be regarded as suspect, insofar as the linguistics trail is concerned. By the same token, languages spoken in that area may also not form part of the linguistic trail.

This also implies that language groups that exhibit a comparable range of intensity may have migrated from, or stayed together in, one and the same area. For instance, it is very difficult to expect language groups with a wide range of intensity to have travelled or spent time together with language groups without a similar range of intensity. Thus, it makes more sense to put together language groups with a comparable range of intensity, and to regard them as having dispersed from, or having spent time together in, the same area. 
How does the preceding discussion apply to the topic of this paper? Proto Nuclear Micronesians did not originate from within Micronesia, but colonised the area from somewhere else. That much is uncontroversial. As discussed in section 2, geographically adjacent areas such as the Admiralty Islands, the St Matthias Islands, the Cristobal-Malaitan region, and the northern Vanuatu have all been put forth as the homeland for Proto Nuclear Micronesians. On the basis of geographical proximity alone, other adjacent areas, i.e. the Marianas, New Ireland, the western Solomon Islands (i.e. Bougainville, Choiseul and Santa Isabel) and Polynesia, should also be included in the list. On present evidence, however, only three areas have emerged as strong candidates for the homeland of Proto Nuclear Micronesians: (i) the northern Vanuatu, (ii) the Cristobal-Malaitan region and (iii) the Admiralty Islands. All located to the south of Micronesia, these areas are more or less spread across the Micronesian chain from east to west in that order. Thus, in terms of geographical propinquity Micronesia could have been settled from any one of the three, albeit with varying degrees of difficulty, or even from all of the three. If, however, there is a linguistic trail of the kind alluded to above, and if Micronesia is located on that trail, then it becomes crucial to ascertain whether or not any of the three areas is also found on the same trail. If, for example, one of the three areas is part of the linguistic trail whereas the other two are not, this will indeed constitute a strong piece of evidence for the former being the homeland of Proto Nuclear Micronesians. Moreover, the other adjacent Oceanic-speaking areas, e.g. New Ireland, the western Solomon Islands and Polynesia, can also be assessed in order to determine whether or not they are located on the same trail, although there currently is no evidence, linguistic or otherwise, for them being the Proto Nuclear Micronesian homeland. ${ }^{\circledR}$ In other words, such a linguistic trail will also offer an opportunity to evaluate other available evidence or data.

\section{The linguistic trail of possessive classifiers}

One of the typological properties that make Nuclear Micronesian languages stand out from the rest of the Oceanic group is that the former, with the sole exception of Gilbertese, have an extremely large number of so-called possessive classifiers, ranging between fifteen and over twenty (Harrison 1988, and Song 1997; cf. Bender 1971: 457). As a matter of fact, Ulithian is reported to have as many as thirty one possessive classifiers (Sohn and Bender 1973: 268-270)! This indeed is a truly striking typological property of Nuclear Micronesian languages. The following examples come from Kusaiean (Lee 1975: 103-105, 242, 262).

\footnotetext{
(1) The Mariana Islands are excluded because non-Oceanic Austronesian languages are spoken there. There is ample evidence that this region was colonised from southeast Asia (e.g. Craib 1983, Bellwood 1989, Intoh 1997).
} 


\section{Jae Jung Song}

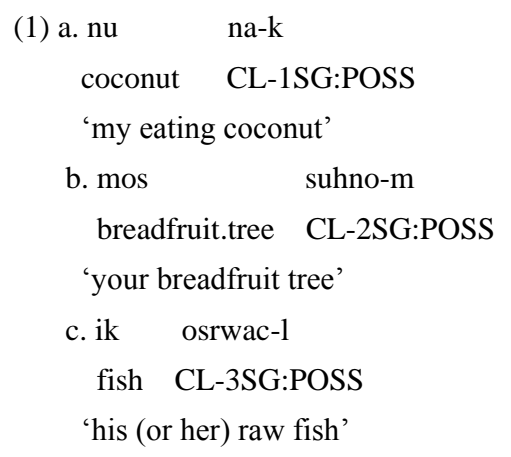

Note that in (1) the possessor marking (i.e. first, second, or third person) is attached directly to the possessive classifier (i.e. na-, suhno- or osrwac-), whereby the semantic or culturally significant relation between the possessor and the possessed (i.e. $n u, m o s, i k$ ) is explicitly indicated (cf. Lichtenberk 1983a, 1983b). Incidentally, Kusaiean has as many as nineteen possessive classifiers (Lee 1975: 110-118). Moreover, given possessor X and possessed $\mathrm{Y}$, the 'edible' possessive classifier expresses that $\mathrm{Y}$ is food to $\mathrm{X}$; the 'drinkable' possessive classifier indicates that $\mathrm{Y}$ is a drink to $\mathrm{X}$, and so forth. It is thus possible that possessed Y, e.g. coconut, can enter into multiple relationships, e.g. food, drink, and plant, with possessor X. This phenomenon is referred to as "overlap" by Lynch (1973: 76). This is also why Lichtenberk (1983a: 148) chooses to refer to possessive classifiers as relational classifiers as opposed to "sortal" (e.g. Allan 1977) or "mensural" classifiers. The overlap is demonstrated nicely by Ulithian (Lichtenberk 1983a: 159, also Sohn and Bender 1973: 270).

(2) a. lawu-yi yixi

CL-may fish

'my fish, that I am keeping' [i.e. intimate property possession]

b. xala-yi yixi

CL-my fish

'my cooked-fish food' [i.e. cooked-food possession]

c. xocaa-yi yixi

CL-my fish

'my raw-fish food' [i.e. raw-food possession]

d. xolo-yi yixi

CL-my fish

'my fish that I caught' [i.e. prey possession] 
In comparison, non-Micronesian Oceanic languages have a much smaller number of possessive classifiers. In point of fact, Pawley (1973) and Lichtenberk (1985) have reconstructed only two or three possessive classifiers for POc, respectively. ${ }^{(1)}$ The size of the possessive classifier system found in Nuclear Micronesian languages truly is something of a marvel.

What this suggests is that Proto Nuclear Micronesian must have had a very strong propensity for enlarging the possessive classifier system to an extent never witnessed anywhere else in the Pacific. Moreover, it is very difficult to imagine that such a strong propensity is something that came into being only after Proto Nuclear Micronesian speakers had entered Micronesia (that is, Proto Nuclear Micronesian had only two or three possessive classifiers when its speakers first arrived in Micronesia). The dramatic increase from two or three possessive classifiers in POc to over twenty in present-day Nuclear Micronesian is something that could not possibly have been achieved in Micronesia alone. To put it differently, Proto Nuclear Micronesians must have carried the propensity for a large number of possessive classifiers in their languages from somewhere else into Micronesia. This in turn points to the distinct possibility that whomever they may have interacted linguistically — and also culturally and genetically — with must have shared the same typological propensity, if not equally strong. Moreover, the area where Proto Nuclear Micronesians intermingled with these people(s) must then have been the former's immediate or last inferable homeland. It is also within the realm of possibilities that Proto Nuclear Micronesians and the latter people(s) may have derived from a third common area. It is expected that Nuclear Micronesian will be located at the higher end of the geographical cline or the linguistic trail of possessive classifiers. The largest size of the possessive classifier system in Oceanic is witnessed in Nuclear Micronesian, after all. By going from this higher end of the geographical cline towards the lower end, it will be possible to trace the migration pathway of Proto Nuclear Micronesians back to their immediate homeland (cf. Figure 1).

\subsection{The data}

In order to substantiate the claim that the linguistic trail of possessive classifiers exists in the Oceanic-speaking world, a survey of all the primary subgroups of Oceanic will be

\footnotetext{
(1) Unlike Lichtenberk (1985), Pawley (1973: 163-164) only tentatively reconstructs *ma- 'drinkable' for POc. Ross (1988: 185), on the other hand, believes "that POc in fact had a somewhat larger collection of ... [possessive] classifiers [than has so far been reconstructed], and that it is the most frequently used which have survived." Lynch (1998: 122-130), on the other hand, seems to share Ross's position but also suggests that some languages (e.g. Micronesian) may further have expanded the possessive classifier system. However, no hard evidence has been provided in support of these views. In the absence of such evidence it is assumed in common with Pawley (1973) and Lichtenberk (1985) that POc had two or three possessive classifiers.
} 


\section{Jae Jung Song}

carried out here. Strictly speaking, geographical areas, not linguistic subgroupings, must be adopted for this purpose. There, however, is a reasonably good degree of correlation between geographical division and linguistic affiliation in the Oceanic-speaking world. Thus, use of linguistic subgroupings will have little bearing on the nature and quality of the data to be collected for the survey. This also seems to be a much more convenient option than to develop a set of criteria for dividing the Oceanic-speaking world into a number of geographical areas (e.g. how many?). Pawley and Ross's (1995: 51-57) nine primary subgroupings of Oceanic, as reproduced in Figure 2, will be utilised for purposes of the present investigation.

FIGURE 2. HIGH-ORDER AND PRIMARY SUBGROUPS OF OCEANIC

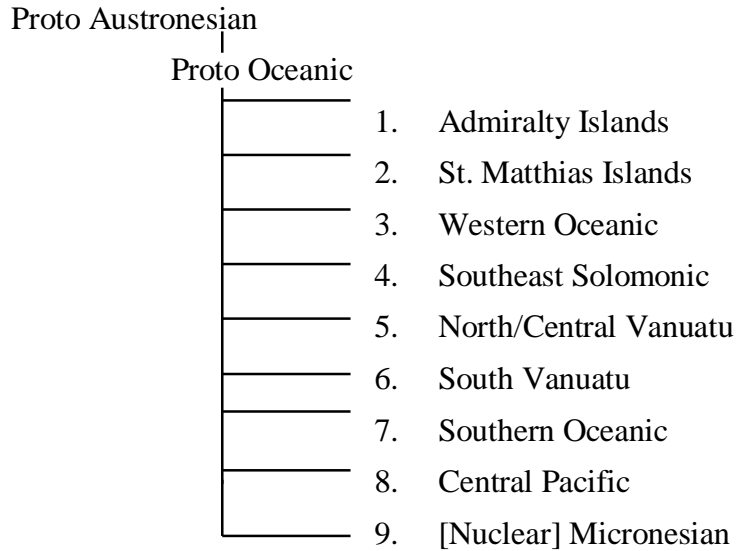

The Oceanic languages referred to or discussed in Lichtenberk $(1985,1986)$ and in Ross (1988) were looked upon as a kind of 'convenience' database, from which languages could freely be selected for purposes of the survey. Not all of the languages listed in Lichtenberk $(1985,1986)$ and Ross (1988) were surveyed, however, because of either unavailability or lack of relevant or reliable information. Also included in the survey were two uncontroversially Austronesian languages of the Eastern Outer Islands, i.e. Asumboa and Tanimbili (Tryon 1994; cf. Lynch and Tryon 1985). These and other Austronesian languages of the area may possibly form a primary subgroup within Oceanic in their own right (Malcolm Ross, pers. comm.; cf. Green 1976a). In addition to these two Eastern Outer languages, four Reefs/Santa Cruz languages from the Eastern Outer Islands, i.e. Nanngu, Reefs, Nea and Löndäi, were included in the survey. There are three reasons for this. First, there is a long-standing debate on whether the Reefs/Santa Cruz languages are Austronesian or Papuan (Wurm 1969, 1972, 1978, and Lincoln 1978). As a matter of fact, their status "as Austronesian or Papuan has never been completely determined" (Tryon 1994: 638). Second, as will later be argued, there is a strong possibility that it was these 
languages (or more accurately their progenitor(s)), not Oceanic languages, that may have been the first to expand the possessive classifier system. Finally and most importantly, the main objective of the survey is to reconstruct population migration, not to establish linguistic subgroupings. Thus, in order to complete the whole picture of the linguistic trail, it is vital to include all (documented) languages of the area in the survey irrespective of their linguistic relationships. There is virtually no information or data on languages of the St Matthias Islands. For what is worth, however, there is one brief reference to the possessive classifier system in one St Matthias language, i.e. Mussau, in Ross's work (1988: 328; and also John Brownie, pers. comm.).

Thus, data on as many as seventy six non-Nuclear Micronesian Oceanic languages and nine Nuclear Micronesian languages were collected from the available sources (i.e. eighty five in total). It has to be admitted, though, that a significant portion of the sample came directly from Smythe's (1970) summary of grammatical properties of twenty three Admiralties languages. Nonetheless, all the primary Oceanic subgroups were reasonably well represented in the sample. The names of the subgroups, followed by the actual number of surveyed languages in parentheses, are: the Admiralty Islands (23), St Matthias Islands (1), Western Oceanic (14), Southeast Solomonic (10), North/Central Vanuatu (8), South Vanuatu (3), Southern Oceanic (5), Central Pacific (6), Eastern Outer Islands (6), and Nuclear Micronesian (9). In Appendix 1, the number of possessive classifiers in each of the sampled languages is given along with the details of bibliographical sources under its appropriate grouping.

\subsubsection{The Admiralty Islands}

Smythe (1970: 1212) provides a brief summary of grammatical properties of twenty three languages from this subgroup. These languages have one or two possessive classifiers, with the sole exception of Ninigo, which has as many as five. There are no languages in this subgroup that completely lack possessive classifiers, however. Thus, the number of possessive classifiers in almost all the Admiralties languages ranges from one to two.

\subsubsection{St Matthias Islands}

In his brief discussion of Mussau, Ross (1988: 328) exemplifies four possessive classifiers. On the other hand, John Brownie (pers. comm.), who has been working on this language, reports that it has at least ten possessive classifiers. Due to lack of published data on St Matthias languages, however, nothing more can be said about this subgroup.

\subsubsection{Western Oceanic}

The majority of the Western Oceanic languages may be said to have two possessive classifiers, although two of these, i.e. Mangap-Mbula and Banoni, seem to have a very dilapidated possessive classifier system. Five or six of these languages completely lack possessive classifiers. One or two have only one possessive classifier. The maximum 


\section{Jae Jung Song}

number of possessive classifiers in Western Oceanic never exceeds the number of POc possessive classifiers, as has been reconstructed by Pawley (1973) and Lichtenberk (1985).

\subsubsection{Southeast Solomonic}

This subgroup is not very different from the Western Oceanic subgroup in terms of the number of possessive classifiers. The majority of these languages range from one to two in size. There are three languages that completely lack possessive classifiers, although one of them, Kwaio, may be said to have remnants of two possessive classifiers (Keesing 1985: 23-24, 115). Thus, the Southeast Solomonic languages can be said to deviate very little from the reconstructed POc (Pawley 1973, Lichtenberk 1985), or from Western Oceanic, insofar as the size of the possessive classifier system is concerned.

\subsubsection{North/Central Vanuatu}

The majority of the North/Central Vanuatu languages have four or more possessive classifiers. In fact, Sakao has as many as seven possessive classifiers (Guy 1974), whereas Ambrym has six (Paton 1971). There are two or three languages which lack possessive classifiers. The number of possessive classifiers in most of the North/Central Vanuatu languages exceeds that in Western Oceanic or Southeast Solomonic.

\subsubsection{South Vanuatu}

Two of the three South Vanuatu languages in the sample, i.e. Lenakel (Lynch 1978) and Anejom (Lynch 1982), exhibit as many as five possessive classifiers. The other language, Sye, completely lacks possessive classifiers (Crowley 1998). This subgroup is thus more akin to North/Central Vanuatu in terms of the number of possessive classifiers than either to Western Oceanic or to Southeast Solomonic.

\subsubsection{Southern Oceanic}

The number of possessive classifiers in this subgroup also ranges from none to possibly more than seven possessive classifiers. Tinrin has seven (Osumi 1995), whereas Iaai is said to have six (Tryon 1968b) or ten (Lynch 1998: 127). There are also two languages with no possessive classifiers (i.e. Dehu and Nengone) and one language with only one possessive classifier (i.e. Ajië).

\subsubsection{Central Pacific}

Fijian stands out from the rest of the Central Pacific subgroup in that it has three possessive classifiers (Milner 1972). The other Central Pacific languages, with the exception of Niuean and Rotuman, have the so-called $o / a$ (i.e. inalienable vs. alienable, or uncontrolled vs. controlled) distinction. Niuean completely lost this Polynesian o/a distinction (Biggs 1971: 470), whereas Rotuman seems to have only a relic of POc possessive classifier *ka- 'edible/subordinate' in one of its so-called possessive prepositions (Churchward 1940: 31, Pawley 1972: 86, 1979: 21-22). The generalised o/a distinction cannot be strictly said to constitute the same type of possessive classifier system 
exhibited by other Oceanic languages, but it may well have been derived from the POc possessive classifier system (see Wilson 1982 for this view). At any rate, the maximum number of possessive classifiers found in Central Pacific does not deviate from what has been reconstructed for POc, notwithstanding its alteration of the original POc possessive classifier system.

\subsubsection{Eastern Outer Islands}

The uncontroversially Austronesian languages in the Eastern Outer Islands, i.e. Asumboa and Tanimbili, each have as many as five possessive classifiers. On the other hand, the four Reef/Santa Cruz languages, which have not yet been classified either as Austronesian or as Papuan, do have far more possessive classifiers than Asumboa and Tanimbili. Nanngu has eleven possessive classifiers, Reefs ten, and Nea eight, but Löndäi has as many as fourteen possessive classifiers (Wurm 1969, 1972, 1978). These languages are the ones in the sample that approximate more closely to Nuclear Micronesian in terms of the size of the possessive classifier system than do any other subgroups. Lincoln (1978) believes these Reefs/Santa Cruz languages to be basically Austronesian. Wurm (1969, 1972, 1978), on the other hand, is firmly of the view that they are Papuan, albeit heavily Austronesianised. (Further discussion of this issue is deferred to 5.3.) Regardless of who is correct, Lincoln or Wurm, the point remains that these languages are the closest to Nuclear Micronesian insofar as the maximum number of possessive classifiers is concerned.

\subsubsection{Nuclear Micronesian}

Not much will be said about this subgroup, except that it exceeds all the others in terms of the number of possessive classifiers by a decisive margin, and that only one Nuclear Micronesian language, Gilbertese, lacks possessive classifiers (cf. Harrison 1988, and Song 1997). Thus, apart from Gilbertese, the size of the possessive classifier system in Nuclear Micronesian ranges from eight to thirty one. It is quite possible that Sonsorolese/Tobian may have more than eight possessive classifiers that they are reported to have (Capell 1969: 28).

\subsection{The geographical cline of possessive classifiers: an interpretation}

The preceding survey points to one significant fact. There are two 'sets' of language subgroups in Oceanic in terms of the quantitative range of possessive classifiers. In Oceanic subgroups such as Western Oceanic, Southeast Solomonic and Central Pacific, the maximum number of possessive classifiers never exceeds that of POc, i.e. two or three. The North/Central Vanuatu, South Vanuatu, Southern Oceanic and Eastern Outer Islands (including the Reefs/Santa Cruz languages) subgroups, on the other hand, contain languages the maximum number of possessive classifiers of which exceeds that of POc by a decisive margin (cf. Appendix 1). When, in fact, the areas where the language subgroups of the second 'set' are spoken are all connected (cf. the darkened areas in Map 1), an 
unbroken or uninterrupted line can literally be drawn from New Caledonia (i.e. Southern Oceanic) all the way to Micronesia (i.e. Nuclear Micronesian). In North/Central Vanuatu, South Vanuatu and Southern Oceanic, languages tend to have four to seven possessive classifiers. This trend continues well into the Eastern Outer Islands, with Asumboa and Tanimbili each having five possessive classifiers. (This area also contains Polynesian Outlier languages, i.e. Pileni and Tikopian-Anutan (Tryon 1994: 613). $)^{\circledR}$ This geographical line is linked ultimately to Micronesia, where the size of possessive classifiers has "exploded" into the range of eight or fourteen to thirty one. Moreover, Reefs/Santa Cruz languages are also located in the Eastern Outer Islands. For instance, one of these languages, Löndäi, is reported to have as many as fourteen possessive classifiers. Thus, right on the doorstep of Micronesia are languages with a nearly comparable size of the possessive classifier system located. With the first 'set' of language subgroups ignored (i.e. lacking the propensity for enlarging the possessive classifier system beyond the size of POc; the undarkened areas in Map 1), the geographical line from New Caledonia to Micronesia may embody two separate clines with Vanuatu as the centre of dispersal: (i) a south-to-north cline from the lower end of intensity to the higher end of intensity, that is from Vanuatu (with zero to seven possessive classifiers) to the Eastern Outer Islands (with five to fourteen possessive classifiers), and to Micronesia (with eight to thirty one possessive classifiers; Gilbertese ignored here) ${ }^{2}$, and (ii) a north-to-south cline from the lower end of intensity to the higher end of intensity, that is from Vanuatu (with zero to seven possessive classifiers) to the Loyalty Islands and New Caledonia (with zero to ten possessive classifiers). Note that Vanuatu has been chosen here as the centre of dispersal, because this area exhibits a low range of intensity on the trail, with areas with a high range of intensity located to both its north and south. The overall geographical cline is claimed to constitute the linguistic trail of the propensity for increasing the size of the possessive classifier system.

\footnotetext{
(1) The arrival of these Polynesian Outlier languages is understood to post-date that of Lapita colonisers and that of western Melanesians (Green 1976a: 50-51).

(2) There is reason to suspect that Gilbertese has lost its possessive classifier system due to Polynesian influence (e.g. Song 1997: 44).
} 
The Migration Pathway of The Proto Nuclear Micronesians: A Linguistic Trail 


\section{Jae Jung Song}

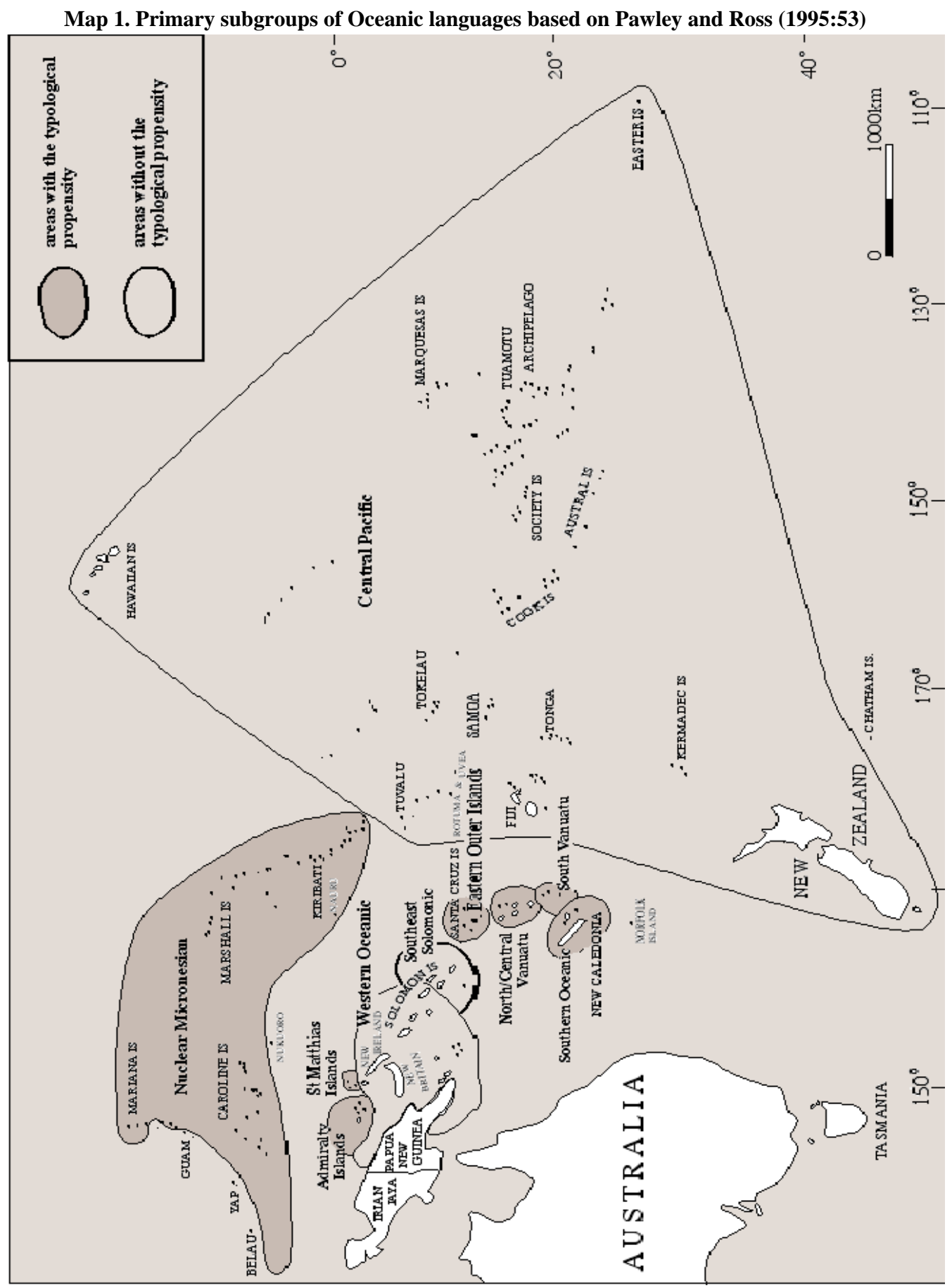


In view of this linguistic trail, it is possible to propose that Proto Nuclear Micronesians may have travelled from somewhere in the south, where the rest of the trail is plotted. This vector of Micronesian migration indeed is reflected in the south-to-north cline of the intensity from Vanuatu to Micronesia (just as the vector of 'New Caledonian' migration is reflected in the north-to-south cline of the intensity from Vanuatu to New Caledonia (e.g. Kirch 1997: 62, 72 and also 5.3)). It may not be clear from the discussion of the trail exactly where their homeland is located. (In fact, it may really be irrelevant where Proto Nuclear Micronesians may ultimately have originated from, insofar as Micronesian prehistory is concerned, because one may eventually have to trace their origin to somewhere in the Vitiaz Strait or the northern New Britain region, the proposed location of POc (Ross 1988).) What is clear, however, is from which direction Proto Nuclear Micronesians may have entered Micronesia. They must have spent some time in the Santa Cruz Islands so that they could develop the propensity for enlarging the possessive classifier system together with Proto Reefs/Santa Cruz Islanders. The fact that the Reefs/Santa Cruz languages exhibit an almost comparable number of possessive classifiers to Nuclear Micronesian is a testament to the distinct possibility that the Santa Cruz Islands may have been the place where Proto Nuclear Micronesians and Proto Reefs/Santa Cruz Islanders really developed the typological propensity before the former, once in Micronesia, finally brought the possessive classifier system into full bloom, as it were. This means that, on the basis of the linguistic trail identified here, the immediate homeland of Proto Nuclear Micronesians may have been the Santa Cruz Islands, or at least that is the area which Proto Nuclear Micronesians left in the direction of Micronesia.

It is also quite possible that Proto Nuclear Micronesians and Proto Reefs/Santa Cruz Islanders may have travelled together from further down south in the trail, e.g. Vanuatu. In this scenario, Proto Nuclear Micronesians alone may then have continued to move further north from the Santa Cruz Islands, leaving Proto Reefs/Santa Cruz Islanders behind. Alternatively, Proto Reefs/Santa Cruz Islanders may have migrated from Vanuatu or somewhere else (e.g. the Solomon Islands) to the Santa Cruz Islands where they met pre-existing Proto Nuclear Micronesians. Whichever scenario is correct, the crucial point is that the two proto languages must have expanded the possessive classifier system together beyond the level witnessed nowhere else in the Pacific before parting company with each other in the Santa Cruz Islands. ${ }^{(1)}$ Thus, the entry point into Micronesia of Proto Nuclear Micronesians is none other than the Santa Cruz Islands.

\footnotetext{
(1) The latter scenario may be in agreement with Green (1976a, 1976b), who argues on the basis of Lapita data that the arrival in the Santa Cruz Islands of non-Austronesian speakers occurred only in the post-Lapita period, because there is no evidence for a pre-Lapita occupation in the Santa Cruz Islands (McCoy and Cleghorn 1988: 112; cf. Spriggs 1984: 207, 1997: 7).
} 
Three different areas have so far been proposed in Oceanic linguistics as the homeland of Proto Nuclear Micronesians: the Admiralty Islands, the Cristobal-Malaitan region, and the northern Vanuatu. The Admiralty Islands (Smythe 1970) may possibly be a potential, albeit not very strong, candidate, because at least one language, i.e. Ninigo, is known to have as many as five possessive classifiers. As a matter of fact, not only the Admiralty Islands but also the St Matthias Islands (i.e. Mussau with ten possessive classifiers) form part of the linguistic trail. These two areas, however, could not have been the departure point for Proto Nuclear Micronesians. The 'transition' from the Admiralty Islands or the St Matthias Islands to Micronesia is far less gradual in terms of intensity than that from the areas on the other side of the trail to Micronesia. From Vanuatu to the Santa Cruz Islands and to Micronesia, the maximum number of possessive classifiers increases reasonably gradually from seven to fourteen to thirty one. By contrast, Ninigo and Mussau have five and ten possessive classifiers, respectively. The difference between five/ten possessive classifiers in the Admiralty/St Matthias Islands and thirty one in Micronesia is much too great to suggest that Proto Nuclear Micronesians may have spent time together with Proto Admiralty or St Matthias Islanders in the Admiralty Islands or the St Matthias Islands, respectively. It is more likely that both Ninigo and Mussau may have borrowed the propensity for enlarging the possessive classifier system from Nuclear Micronesian some time after the colonisation of Micronesia. Also noteworthy in this context is that the maximum level of intensity in the Admiralty Islands or the St Matthias Islands has barely reached the minimum level of intensity in Micronesia. This suggests that the existence of a relatively high number of possessive classifiers in Ninigo or Mussau, in comparison with Western Oceanic or Southeast Solomonic, may well be due to comparatively recent contact between the two languages and Nuclear Micronesian (e.g. Spriggs 1997: 195), in fact, so recent that the level of intensity in the Admiralty Islands or the St Matthias Islands has not yet stabilised. As evidence in support of this view, attention is drawn to the fact that the size of the possessive classifier system in all other languages of the Admiralty Islands subgroup ranges only from one to two possessive classifiers, much smaller than that of North/Central Vanuatu, South Vanuatu and Southern Oceanic languages.

In the light of the linguistic trail, the second candidate, the Cristobal-Malaitan region (Blust 1984), turns out to be an extremely poor candidate for the Micronesian homeland. Languages spoken in that region (i.e. the Southeast Solomonic subgroup) do not even form part of the linguistic trail.

The picture emerging from the preceding discussion does not exactly match the migration scenario built on Pawley's $(1972,1977)$ subgrouping hypothesis and also Shutler and Marck (1975), i.e. the northern Vanuatu. However, at least this area is connected directly with the Santa Cruz Islands not only in geographical terms, but also, more 
importantly, in terms of the linguistic trail. Proto Nuclear Micronesians may very well have reached the Santa Cruz Islands from northern Vanuatu. (They must have come from somewhere else to the Santa Cruz Islands!) If this is correct, it may also be possible to argue that Proto Nuclear Micronesians may have travelled from somewhere in northern Vanuatu or at least from that direction to the Santa Cruz Islands. In this context, it is also worth taking note of the relatively long distance between northern Vanuatu and Micronesia, as opposed to that between either the Admiralty Islands or the St Matthias Islands and Micronesia. The distance between northern Vanuatu and Micronesia is matched by the gradually increasing intensity between them. The short distance between the Admiralty Islands or the St Matthias Islands and Micronesia, on the other hand, is matched by the abruptly increasing intensity between them. This may suggest that the 'transition' from northern Vanuatu to Micronesia may be of greater antiquity than that from either the Admiralty Islands or the St Matthias Islands to Micronesia. This in turn implies that the large size of the possessive classifier system witnessed in Micronesia may have derived from northern Vanuatu rather than from either the Admiralty Islands or the St Matthias Islands.

Of the three potential homelands for Proto Nuclear Micronesians, then, only the one derived from Pawley's $(1972,1977)$ hypothesis (or Shutler and Marck's (1975)) fits in broadly with what the linguistic trail of the typological propensity suggests: the Santa Cruz Islands and, prior to that, possibly the northern Vanuatu.

\section{Non-linguistic evidence in support}

In the previous section the linguistic trail of the typological propensity points clearly to the Santa Cruz Islands and possibly also northern Vanuatu as the location from which Proto Nuclear Micronesians may have entered Micronesia. It is now worth discussing in some detail how the migration pathway implied by the linguistic trail is supported by data or evidence arising from disciplines other than linguistics, i.e. archaeology and genetics.

\subsection{Archaeological evidence}

As has already been hinted at in the Introduction, there is much archaeological evidence in support of the southeast Solomons and northern Vanuatu as the homeland of Proto Nuclear Micronesians. It must be remembered, however, that, when archaeologists (e.g. Athens 1990a, 1990b, 1995) speak of the southeast Solomons, insofar as Lapita pottery evidence is concerned, they are referring only to the Santa Cruz Islands, and not to the eastern part of the Solomon Islands chain proper, e.g. the Cristobal-Malaitan region. This is because no Lapita sites, apart from an artefact assemblage on Guadalcanal, have yet been 


\section{Jae Jung Song}

discovered in the Solomon Islands west of the Santa Cruz Islands (Green 1979: 51, Spriggs 1984: 208-209, 1995: 113, 1996, Kirch 1997: 53). ${ }^{\circledR}$ Although such sites may in the future be discovered in the Solomon Islands proper (Green 1979: 51; Spriggs 1984: 210-213), it must be borne in mind that only the Santa Cruz Islands is meant by the southeast Solomons when pottery evidence is discussed. This is important, especially when in linguistics the Southeast Solomonic subgroup consists of languages spoken in the Solomon Islands chain west of the Santa Cruz Islands, and not those spoken on the Santa Cruz Islands (i.e. Eastern Outer Islands).

The archaeological evidence comes from pottery excavated in the volcanic islands of Micronesia, namely Pohnpei, Truk and Kosrae. Athens (1990a, 1990b, 1995), for instance, proposes that the origins of the Pohnpeian settlers and, also perhaps, those of Truk and Kosrae may have been derived from the southeast Solomon and New Hebrides (or Vanuatu) Islands, because the Pohnpei sherds, with relatively little decoration, have a clear linkage with the late Lapita Plain Ware pottery tradition found in various locations in the southeast Solomons and New Hebrides Islands (Green 1976b, 1979, 1991, Kirch 1983, 1997, McCoy and Cleghorn 1988, Spriggs 1984, 1995). The conclusion reached at the end of the previous section, based on the interpretation of the linguistic trail, fits in very comfortably with this archaeological evidence.

There may also be evidence from non-pottery material cultural artefacts. Accordingly, Davidson (1988: 93) reminds Oceanic prehistorians that eastern Melanesia has a lot to offer itself as a potential Micronesian homeland. In particular, she takes note of various artefacts including shell adzes, slingstones, fishhooks, shell peelers and a variety of shell ornaments, which have an antiquity of up to 3,000 years in the Santa Cruz area (also see Kirch 1983, McCoy and Cleghorn 1988, Green 1976b, 1991, and Irwin 1992: 128). ${ }^{(2)}$ Mention must also be made of ample archaeological evidence for later contact between the two areas, which may be a good indication of earlier contact. For instance, Intoh $(1996,1997)$ provides material-cultural evidence for later contact between the two. Kirch (1983: 81) also refers to stone fishtraps located on Vanikoro (in the Santa Cruz Islands). This particular

\footnotetext{
(1) There is "a Lapita void" in the large islands stretching between Bougainville and San Cristobal (Kirch 1997: 53).

(2) There are some Melanesianists who suggest that eastern Melanesia received some cultural influence from Micronesia, especially in relation to the origin and spread of Terebra shell adzes in Micronesia and their relatively late appearance in Santa Cruz and Vanuatu. Intoh (1997: 25), however, argues that the antiquity of these shell adzes in Micronesia is questionable, because none have been found from the early pottery bearing site in Truk (Shutler et al. 1984). Thus, she is of the opinion that it is more plausible to suggest that the shell tool was imported from eastern Melanesia into Micronesia than vice versa.
} 
type of stone fishtrap, seldom reported for Melanesia, is also known widely throughout parts of Micronesia. ${ }^{(1)}$

\subsection{Genetic evidence}

Recent advances in genetics, especially in DNA analysis, have also contributed to our understanding of population migration in different parts of the world. The Pacific is no exception to this. In fact, "a disproportionately large number of surveys of haemoglobin variants ... and an even more generous share of DNA studies" have over the years been carried out on Pacific Islanders (Hill et al. 1989: 246). Not surprisingly, evidence and data arising from these studies have often been utilised to support one migration hypothesis in preference to another. For example, O'Shaughnessy et al. (1990: 150-151) have identified the $\zeta \zeta \zeta$ chromosome as a useful Austronesian genetic marker. These geneticists have discovered that the triplicated- $\zeta$-gene chromosome - first found in Southeast Asians, but very rare in the rest of Eurasia and Africa (Higgs et al. 1986) - has the structure of an unusual hybrid Ia/IIe haplotype (also see Hill et al. 1989: 265-267). Their research has also revealed that all the chromosomes from Southeast Asia and the Pacific have the same hybrid Ia/IIe haplotype structure, thereby suggesting that this particular gene must have had a single origin and been spread by migration through Southeast Asia, island Melanesia, Micronesia and Polynesia. Moreover, the wholly Melanesian origin for the Polynesians proposed by Terrell (1986), and White et al. (1988) has been proven untenable in view of the presence of so many non-Melanesian genes in Polynesians, e.g. high frequencies of the a-globin haplotypes Ia and IIa (Hill et al. 1989: 275-276; also Serjeantson and Hill 1989: 287).

The archaeologist Matthew Spriggs (1995: 123; also Kirch 1997: 106) notes rightly that "[f]or many of the more recently discovered genetic systems, sample coverage is spotty compared to that in archaeology and linguistics." Nonetheless, there is sufficient genetic evidence, especially from the DNA analysis of haemoglobin and globin gene variants in the Pacific (Hill et al. 1989, O'Shaughnessy et al. 1990), which broadly supports the migration pathway of Proto Nuclear Micronesians suggested by the linguistic trail. Thus, Hill et al. (1989) and O'Shaughnessy et al. (1990) recognize the $-\alpha^{3.7}$ III chromosome as the prime island Melanesian genetic marker, and then trace the trail of this genetic marker through the Pacific. This particular chromosome, which is the commonest type of $\alpha^{+}$(or mild) thalassaemia in most of island Melanesia, has the highest frequency in northern Vanuatu, in parts of the Solomon Islands, and in the Bismarck Archipelago (Flint et al. 1986). The

\footnotetext{
(1) Lewis (1994: 59) takes note of physical similarities between Micronesian and Santa Cruz canoes, although Ninigo (the Admiralty Islands) canoes also are said to bear much resemblance to Micronesian ones.
} 


\section{Jae Jung Song}

same $-\alpha^{3.7}$ III deletion is found, albeit at a low frequency, also on several Micronesian islands east of Palau (Hill et al. 1989: 257, O’Shaughnessy et al. 1990: 149), e.g. Tarawa, Majuro, Truk, and Pohnpei. This leads to the conclusion that the genetic feature in question must have entered the Micronesian gene pool "by northward migration from Melanesia" (O’Shaughnessy 1989: 153). The reverse direction of migration, i.e. from Micronesia into Melanesia, must be rejected in view of evidence for natural selection of $\alpha^{+}$thalassaemia alleles by malaria (Flint et al. 1986). Micronesia, unlike island Melanesia, has always been known to be free from malaria. This will indeed make it very difficult to explain why there is such a significant amount of $\alpha^{+}$thalassaemia in Micronesia in the first place (O'Shaughnessy et al. 1990: 152-153), unless Proto Nuclear Micronesians acquired it from island Melanesians en route to Micronesia. Moreover, O'Shaughnessy et al. (1990: 148) point also to the significant presence in Micronesia of the IIIa, IVa and Vc haplotypes, which predominate within Melanesia, as evidence in support of "a substantial Melanesian input into the Micronesian and Polynesian gene pools". In fact, Hill et al. (1989: 278) go so far as to say that "the DNA markers provide unequivocal evidence of some Melanesian gene flow into present-day Micronesians."

As noted above, Micronesians and Polynesians have some Melanesian genetic markers in common, e.g. the $-\alpha^{3.7}$ III deletion and the high frequencies of the $\alpha$-globin haplotypes IIIa and IVa. However, the two groups do differ from each other in that the former have acquired one additional Melanesian genetic marker which the latter have not, i.e. the $-\alpha^{4.2}$ deletion. This particular type of $\alpha^{+}$thalassaemia has actually been identified as a north coastal New Guinea marker (Flint et al. 1986). The frequency of the $-\alpha^{4.2}$ deletion in the north coast of New Guinea exceeds 50 per cent, and has also been discovered in the northern Solomon Islands, and in Vanuatu and New Caledonia, albeit at a lower frequency. ${ }^{(1)}$ The $-\alpha^{4.2}$ deletions found in Micronesia, albeit at a low frequency, all have the Melanesian IIIa haplotype (O'Shaughnessy et al. 1990). What is of significance is, however, that this type of $\alpha^{+}$thalassaemia is absent in Polynesians including Fijians (Hill et al. 1989: 256). This strongly suggests that Proto Nuclear Micronesians and Proto Polynesians may have stayed in island Melanesia for different lengths of time prior to their departures. Proto Polynesians may have "moved rapidly through this part of Melanesia [i.e.

\footnotetext{
(1) Bellwood (1989: 41) believes that this particular genetic marker was brought to the areas by new migrant Melanesian groups who arrived after the settlement of Lapita people (also see Pawley and Ross 1993: 446). In his words, "the Lapita settlers were evidently 'caught up' very rapidly by other western Melanesian migrant populations". He also thinks that these Melanesian migrants were Austronesian speakers as a result of interaction between original Papuan-speaking horticultural populations, and Austronesian-speaking Lapita settlers in western Melanesia. Wurm (1970: 548), on the other hand, does not rule out the possibility that they were Papuan speakers.
} 
island Melanesia east of the Solomons]", although "the presence of a substantial frequency of Melanesian $\alpha$-globin haplotypes IIIa and IVa in all Polynesians indicates that at some point there was significant interbreeding [with] Melanesians" (Serjeantson and Hill 1989: 287). Proto Nuclear Micronesians, on the other hand, must have stayed longer and interbred more with Melanesian neighbours since they have also acquired the north coastal New Guinea marker, the $-\alpha^{4.2}$ deletion. It is very plausible, then, that Proto Nuclear Micronesians may have spent a considerable amount of time in this part of the Pacific while this genetic marker was spreading throughout there. In other words, Proto Nuclear Micronesians must have left the region only after Proto Polynesians had done so.

The preceding genetic evidence, however, does not pinpoint the entry point of Proto Nuclear Micronesians; it indicates merely that they may have entered Micronesia "by northward migration from Melanesia" (O'Shaughnessy 1989: 153). Thus, the genetic evidence does not completely rule out the direct migration route either from Vanuatu or from the north Solomon Islands. The migration scenario based on the linguistic trail, on the other hand, points precisely to the Santa Cruz Islands as the area from which Proto Nuclear Micronesians reached Micronesia, although they may have possibly travelled earlier from Vanuatu. Unfortunately, there seems to be no genetic research carried out on present-day Santa Cruz Islanders relative to Nuclear Micronesians. Such research may possibly lead to discovery of additional genetic markers which make a finer discrimination between Micronesians and Santa Cruz Islanders on the one hand, and inhabitants of Vanuatu and the Solomon Islands on the other, for instance. Moreover, in view of the linguistic trail, it is predicted that Santa Cruz Islanders will also have the same range of genetic markers that are found in present-day Micronesians, e.g. the $-\alpha^{3.7}$ III deletion and the $-\alpha^{4.2}$ deletion.

\subsection{Summary}

In the guise of a summary, it may be worth - no matter how speculative it may be attempting to reconcile the linguistic trail with the fact that Micronesians, not Polynesians, have acquired the north coastal New Guinea (or, broadly speaking, Melanesian) genetic marker of the $-\alpha^{4.2}$ deletion, although the two groups may both have dispersed from island Melanesia. On the basis of the presence of the $-\alpha^{4.2}$ deletion, Proto Nuclear Micronesians are thought to have stayed longer in island Melanesia than Proto Polynesians. To put it differently, the departure of Proto Polynesians may have been either before or very shortly after the arrival of migrant Melanesian populations (probably from north coastal New Guinea) who carried the $-\alpha^{4.2}$ deletion in their $\alpha-$ globin genes (also see note 14). (Recall, however, that Proto Polynesians took with them into Polynesia the other type of $\alpha^{+}$ thalassaemia, i.e. the $-\alpha^{3.7}$ III deletion, which they had acquired while in island Melanesia (Hill et al. 1989: 274-275; also Serjeantson and Hill 1989: 287-288).) In contrast, Proto Nuclear Micronesians stayed on and interbred with these new Melanesian arrivals to the 


\section{Jae Jung Song}

effect that the former also picked up the $-\alpha^{4.2}$ deletion from the latter. Kirch (1997: 106), for instance, estimates the temporal difference between Proto Polynesians' departure and Proto Nuclear Micronesians' subsequent departure to be in the neighbourhood of a thousand years.

In 4.2, it was pointed out that in the Eastern Outer Islands it is the Reefs/Santa Cruz languages, not the uncontroversially Austronesian languages (e.g. Utupua and Vanikoro), that approximate very closely to Nuclear Micronesian languages in terms of the number of possessive classifiers. As the reader will also recall, it has not yet been determined whether these Reefs/Santa Cruz languages are Austronesian or Papuan. If, however, it is assumed in common with Wurm $(1969,1970,1972,1978)$ that they are Papuan, the present situation in the Eastern Outer Islands becomes intriguing in that the Papuan languages, with nearly as many possessive classifiers as Nuclear Micronesian languages, and the Austronesian languages, with only one third or even less of the size of the Nuclear Micronesian possessive classifier system, are spoken side by side in the same area (not to mention the Polynesian Outlier languages). At some point in the prehistoric past, Proto Nuclear Micronesian, Proto Eastern Outer Islands (i.e. the ancestral language of the Austronesian Eastern Outer languages) and Proto Reefs/Santa Cruz may presumably all have been spoken in the Santa Cruz Islands. Given that the first two are Austronesian, and the last Papuan, the Austronesian languages, not Papuan languages, are expected to have a possessive classifier system comparable in size to that of Nuclear Micronesian (i.e. Oceanic/Austronesian) languages. That is to say, if the propensity for enlarging the possessive classifier system had originated from Oceanic or Austronesian languages, present-day Nuclear Micronesian and Austronesian Eastern Outer languages should be much closer to each other in terms of the size of the possessive classifier system than they actually are. This is not the case, however. Thus, Proto Nuclear Micronesian must have shared the typological propensity with Proto Reefs/Santa Cruz to a much greater extent than with Proto Eastern Outer Islands. What this suggests strongly is that in the Eastern Outer Islands it was Proto Reefs/Santa Cruz, not Proto Nuclear Micronesian or Proto Eastern Outer Islands, that initially developed the propensity for expanding the possessive classifier system, although the former may originally have borrowed the system from (either of) the latter two (or from other Oceanic languages elsewhere). But what if this scenario extends beyond the Eastern Outer Islands?

It has been proposed that western Melanesian populations migrated to Vanuatu and New Caledonia in the footsteps of Oceanic-speaking Lapita colonisers (Bellwood 1989: 41; also Green 1976a, 1976b, and Spriggs 1997: 40-42). These western Melanesians may have acquired the possessive classifier system from Oceanic-speaking neighbours in either western or eastern Melanesia (but see below). More importantly, they may also have begun 
to expand the newly acquired system in their own languages. This propensity for enlarging the system may then have been 'borrowed' back into Oceanic languages which they came in contact with in eastern Melanesia. This may explain why Oceanic languages spoken in Vanuatu (i.e. North/Central and South Vanuatu), and New Caledonia (i.e. Southern Oceanic) also exhibit a larger possessive classifier system than the reconstructed POc counterpart. After all, these areas were settled by western Melanesian populations reaching there soon after Lapita colonisers (e.g. Bellwood 1989: 41, Pawley and Ross 1993: 446). It may well have been migrant Melanesian populations, not Lapita colonisers, that initially began to increase the size of the Oceanic possessive classifier system in their languages.

Moreover, the fact that Western Oceanic and Southeast Solomonic languages do not exhibit a large number of possessive classifiers, in fact, only one or two, may suggest that migrant western Melanesians may have begun to expand the possessive classifier system in their languages only after they had moved east beyond the main Solomon Islands chain. It is possible that migrant western Melanesians may have borrowed the possessive classifier system from Oceanic-speaking neighbours in western Melanesia and before sailing eastwards. This may concur with Wurm's (1970: 548) interpretation of Austronesian lexical items also attested in Reefs/Santa Cruz languages. He (1970: 548) believes that Proto Reefs/Santa Cruz may have borrowed these lexical items from Austronesian/Oceanic languages while in its place of origin, i.e. the north-eastern part of New Guinea. ${ }^{(1)}$ However, it is also equally possible that migrant western Melanesians may have acquired the possessive classifier system only after they had reached eastern Melanesia or passed the main Solomon Islands chain. ${ }^{2}$ This may be in line with Green's (1976a: 51-55, 60) interpretation of the Austronesian lexical items in Reefs/Santa Cruz languages. He (1976a: 55) argues that Reefs/Santa Cruz languages must have borrowed the Austronesian lexical items from the Austronesian languages of Utupua and Vanikoro in the Santa Cruz Islands, for instance. Insofar as the possessive classifier system is concerned, Green's (1976a) scenario seems more attractive, because in western Melanesia there were Papuan-speaking populations preceding Oceanic-speaking Lapita settlers, whereas, south and east of the main Solomon Islands chain, "there is no clear evidence of human settlement earlier than the Lapita culture, dating in Vanuatu and New Caledonia to about 1200 BC" (Spriggs 1995: 115; also see Spriggs 1997: 40-42). Migrant western Melanesian are more likely to have borrowed the possessive classifier system from pre-existing Lapita populations in eastern

\footnotetext{
(1) Tryon (1994: 636) opines that part of this Austronesianisation of the Reefs/Santa Cruz languages "may have been initiated before the communities bearing the languages reached the Solomons".

(2) Incidentally, the distance between western and eastern Melanesia is "the first significant stretch of open ocean encountered west of New Guinea" (Green 1976a: 15).
} 
Melanesia than from Lapita settlers amid pre-existing dominant Melanesian populations in western Melanesia (cf. Bellwood 1989: 41).

The preceding speculation leads to another one that, while in eastern Melanesia (i.e. the Santa Cruz Islands and/or northern Vanuatu), Proto Nuclear Micronesians may have acquired the genetic marker, i.e. the $-\alpha^{4.2}$ deletion, from migrant western Melanesian populations at about the same time when the former borrowed the propensity for enlarging the possessive classifier system back from the latter. Proto Polynesians, on the other hand, acquired neither the $-\alpha^{4.2}$ deletion nor the typological propensity from these Melanesian populations. They simply did not stay in eastern Melanesia long enough for the two things to happen for them, as it were. Indeed, almost all present-day Polynesian languages exhibit a radically different, highly generalised, possessive marking system, that is, the o/a distinction, with the exception of Fijian, which has (retained) three possessive classifiers. ${ }^{(1)}$

The preceding discussion is, needless to say, highly speculative, but it is a very interesting hypothesis deserving of further investigation. Should it turn out to be more than a mere speculation, then what is remarkable will be that the evidence that distinguishes Micronesians from Polynesians and vice versa can be drawn not only from genetics but also from linguistics.

\section{Concluding remarks}

The linguistic trail of the typological propensity points to the Santa Cruz Islands and possibly also to northern Vanuatu as the immediate homeland of Proto Nuclear Micronesians. Insofar as historical-comparative linguistics is concerned, the main conclusion of the present paper is not completely incompatible with Pawley's $(1972,1977)$, and Shutler and Marck's (1975) subgrouping hypotheses. This conclusion also accords very well with both archaeological and genetic evidence. Based on the evidence from recovered pottery and cultural material artefacts, the southeast Solomons (i.e. the Santa Cruz Islands) and northern Vanuatu have indeed been identified by archaeologists as the homeland of Proto Nuclear Micronesians. Geneticists, on the other hand, have proposed a much broader area of (northern) island Melanesia as the Proto Nuclear Micronesian homeland. Needless to say, this is not due to lack of precision in genetics-based population migration research but rather due to the relatively small number of sampled populations (Kirch 1997: 106). As the scope of their research is widened, geneticists will no doubt be able to locate the homeland of Proto Nuclear Micronesians in a more precise fashion.

\footnotetext{
(1) This may not come as a total surprise in view of the position of Fiji as the cultural, genetic, linguistic bridge between Melanesia and Polynesia.
} 
The migration pathway of Proto Nuclear Micronesians as proposed here on the basis of the linguistic trail is deemed plausible also in physical terms. That is, there are no reasons to regard the settlement of Micronesia by direct voyage from the Santa Cruz Islands as improbable, as Irwin (1992) demonstrates by means of computer simulation. He explains that in one of his computer simulations, consisting of ten canoes sailing from the Reefs Islands by using realistic navigational skills, "[o]ne canoe reaches Banaba [a Gilbertese-speaking island located in between the Gilbert Islands and Nauru], two reach Kiribati ... [and t]he rest find seven separate landfalls in the Marshall Islands, three on the return leg of the journey after turning to sail home." (1992: 122) This particular test was carried out on the assumption that the canoes sailed off in January, "a more difficult time", when they had to "sail into the trade wind season of the northern hemisphere winter" (Irwin 1992: 122). Clearly, direct voyage from the Santa Cruz Islands to Micronesia is navigationally possible and feasible.

Finally, it goes without saying that the evidence from the linguistic trail is very limited. More languages have to be surveyed in order to strengthen the validity of the linguistic trail. Moreover, future research will need to look into the possibility of discovering other linguistic trails that may add weight to (or, as the case may be, detract from) the migration pathway of Proto Nuclear Micronesians that has been proposed here. ${ }^{\circledR}$ For these reasons alone, the nature of the present paper is highly exploratory and speculative. It is hoped, nonetheless, that it has achieved its objective of demonstrating the possibility of utilising typological evidence in population migration research.

\section{Appendix 1: Languages of the Sample}

PRIMARY SUBGROUPS; Individual languages; (Sources); [Total Number of Possessive Classifiers]; For the sake of convenience, the Reefs/Santa Cruz languages are placed under Eastern Outer Islands. (N.B.: ?? $=$ possibly; ? = maybe; $\mathrm{X} \approx \mathrm{Y}$, where $\mathrm{X}$ and $\mathrm{Y}$ represent the quantitative range of possessive classifiers)

\begin{tabular}{ll}
\hline THE ADMIRALTY ISLANDS: $[1 \approx 5]$ & \\
\hline Andra & (Smythe 1970) [2] \\
Aua & (Smythe 1970) [1] \\
Baluan & (Smythe 1970) [1] \\
Buyang & (Smythe 1970) [2] \\
Hus & (Smythe 1970) [2] \\
Levei & (Smythe 1970) [2] \\
Luf & (Smythe 1970) [2]
\end{tabular}

\footnotetext{
(1) Bender (1971: 457) mentions other typical Micronesian linguistic properties including elaborate demonstrative systems correlating with person categories and classification of nouns by numerals. The present writer's preliminary investigation has revealed, however, that elaborate demonstrative systems seem to be confined to Nuclear Micronesian languages. They are not attested in any other Oceanic subgroups.
} 
Jae Jung Song

\begin{tabular}{|c|c|}
\hline $\begin{array}{ll}\text { M'bunai } \\
\text { Mokareng } \\
\text { Mundrau } \\
\text { Ninigo } \\
\text { Nyada } \\
\text { Pak } \\
\text { Pityilu } \\
\text { Ponam } \\
\text { Rambutyo } \\
\text { Sabon } \\
\text { Sisi } \\
\text { Sori } \\
\text { Taui } \\
\text { Tulu } \\
\text { Warembu } \\
\text { Yiru } \\
\end{array}$ & $\begin{array}{l}\text { (Smythe 1970) [1] } \\
\text { (Smythe 1970) [2] } \\
\text { (Smythe 1970) [1] } \\
\text { (Smythe 1970) [5] } \\
\text { (Smythe 1970) [1] } \\
\text { (Smythe 1970) [1] } \\
\text { (Smythe 1970) [1] } \\
\text { (Smythe 1970) [1] } \\
\text { (Smythe 1970) [1] } \\
\text { (Smythe 1970) [1] } \\
\text { (Smythe 1970) [2] } \\
\text { (Smythe 1970) [2] } \\
\text { (Smythe 1970) [2] } \\
\text { (Smythe 1970) [2] } \\
\text { (Smythe 1970) [1] } \\
\text { (Smythe 1970) [1] }\end{array}$ \\
\hline \multicolumn{2}{|c|}{ ST MATTHIAS ISLANDS: insufficient information } \\
\hline Mussau & (John Brownie, pers. comm.) [10] \\
\hline \multicolumn{2}{|l|}{ WESTERN OCEANIC: $[0 \approx 2]$} \\
\hline $\begin{array}{ll}\text { Adzera } \\
\text { Balawaia } \\
\text { Banoni } \\
\text { Kairiru } \\
\text { Koliai-Kove } \\
\text { Labu } \\
\text { Lara } \\
\text { Manam } \\
\text { Mangap-Mbula } \\
\text { Mono-Alu } \\
\text { Nakanai } \\
\text { Nissan } \\
\text { Tigak } \\
\text { Tolai } \\
\end{array}$ & $\begin{array}{l}\text { (Holzknecht 1986) [0] } \\
\text { (Kolia 1975) [1] } \\
\text { (Lincoln 1976) [2?] } \\
\text { (Wivel 1981) [0] } \\
\text { (Counts 1969) [2] } \\
\text { (Siegel 1984) [0] } \\
\text { (Lanyon-Orgill 1945) [1??] } \\
\text { (Lichtenberk 1983b) [2] } \\
\text { (Bugenhagen 1995) [2] } \\
\text { (Fagan 1986) [2] } \\
\text { (Johnston 1980) [0] } \\
\text { (Todd 1978) [2] } \\
\text { (Beaumont 1979) [0] } \\
\text { (Mosel 1984) [2] }\end{array}$ \\
\hline \multicolumn{2}{|l|}{ SOUTHEAST SOLOMONIC: $[0 \approx 2]$} \\
\hline $\begin{array}{ll}\text { Arosi } \\
\text { Bugotu } \\
\text { Inakona } \\
\text { Kwara'ae } \\
\text { Kwaio } \\
\text { Longgu } \\
\text { Oroha } \\
\text { To'aba'ita } \\
\text { Ulawa } \\
\text { Vaturanga } \\
\end{array}$ & $\begin{array}{l}\text { Capell 1971) [1 or 2?] } \\
\text { (Ivens 1933) [2] } \\
\text { (Capell 1930) [2??] } \\
\text { (Deck 1933-1934) [0] } \\
\text { (Keesing 1985) [0?] } \\
\text { (Ivens 1934a) [1] } \\
\text { (Ivens 1926-1928) [1 or 2??] } \\
\text { (Lichtenberk 1984) [0] } \\
\text { (Ivens 1913-1914) [1? or 2??] } \\
\text { (Ivens 1934b) [2] } \\
\end{array}$ \\
\hline \multicolumn{2}{|l|}{ NORTH-CENTRAL VANUATU: [0 $\approx 7]$} \\
\hline $\begin{array}{ll}\text { Ambrym } \\
\text { Atchin } \\
\text { Big Nambas } \\
\text { Namakir } \\
\text { Nguna }\end{array}$ & $\begin{array}{l}\text { (Paton 1971) [6] } \\
\text { (Capell and Layard 1980) [4] } \\
\text { (Fox 1979) [1?] } \\
\text { (Sperlich 1991) [0] } \\
\text { (Schütz 1969) [0] }\end{array}$ \\
\hline
\end{tabular}


The Migration Pathway of The Proto Nuclear Micronesians: A Linguistic Trail

\begin{tabular}{|c|c|}
\hline $\begin{array}{l}\text { Paamese } \\
\text { Raxa } \\
\text { Sakao }\end{array}$ & $\begin{array}{l}\text { (Crowley 1982) [4] } \\
(\text { Walsh 1966) [4] } \\
(\text { Guy 1974) }[7] \\
\end{array}$ \\
\hline \multicolumn{2}{|l|}{ SOUTH VANUATU: $[0 \approx 5]$} \\
\hline $\begin{array}{ll} & \text { Anejom } \\
& \text { Lenakel } \\
& \text { Sye } \\
\end{array}$ & $\begin{array}{l}(\text { Lynch 1982) [5] } \\
\text { (Lynch 1978) [5] } \\
\text { (Crowley 1998) [0] } \\
\end{array}$ \\
\hline \multicolumn{2}{|l|}{ SOUTHERN OCEANIC: $[0 \approx 10]$} \\
\hline $\begin{array}{ll}\text { Ajië } \\
\text { Dehu } \\
\text { Iaai } \\
\text { Nengone } \\
\text { Tinrin } \\
\end{array}$ & $\begin{array}{l}\text { Lichtenberk 1978) [1] } \\
\text { (Tryon 1968a) [0] } \\
\text { (Tryon 1968b, Lynch 1998) [6 or 10] } \\
\text { (Tryon 1967) [0] } \\
\text { (Osumi 1995) [7] }\end{array}$ \\
\hline \multicolumn{2}{|l|}{ CENTRAL PACIFIC: $[0 \approx 3]$} \\
\hline $\begin{array}{ll}\text { Fijian } \\
\text { Ma@ ori } \\
\text { Niuean } \\
\text { Rapanui } \\
\text { Rotuman } \\
\text { Samoan } \\
\end{array}$ & $\begin{array}{l}\text { (Milner 1972) [3] } \\
\text { (Bauer 1993) [2?] } \\
\text { (Seiter 1980) [0] } \\
\text { (De Feu 1996) [2?] } \\
\text { (Churchward 1940) [1? or 2??] } \\
\text { (Mosel and Hovdhaugen 1992) [2?] }\end{array}$ \\
\hline \multicolumn{2}{|l|}{ EASTERN OUTER ISLANDS: [ $5 \approx 14]$} \\
\hline $\begin{array}{ll}\text { Asumboa } \\
\text { Löndäi } \\
\text { Nanggu } \\
\text { Nea } \\
\text { Reefs } \\
\text { Tanimbili } \\
\end{array}$ & $\begin{array}{l}\text { (Tryon 1994, per. comm.) [5] } \\
\text { (Wurm 1972) [14] } \\
\text { (Wurm 1972) [11] } \\
\text { (Wurm 1972) [8] } \\
\text { (Wurm 1972) [10] } \\
\text { (Tryon 1994, pers. comm.) [5] }\end{array}$ \\
\hline \multicolumn{2}{|l|}{ NUCLER MICRONESIAN: $[0 \approx 31]$} \\
\hline $\begin{array}{l}\text { Gilbertese } \\
\text { Kusaiean } \\
\text { Marshallese } \\
\text { Mokilese } \\
\text { Ponapean } \\
\text { Sonsorolese/Tobian } \\
\text { Trukese } \\
\text { Ulithian } \\
\text { Woleaian }\end{array}$ & $\begin{array}{l}\text { (Groves, Groves and Jacobs 1985) [0] } \\
\text { (Lee 1975) [19] } \\
\text { (Bender 1969, Zewen 1977) [14 or 15] } \\
\text { (Harrison 1976) [14 or more] } \\
\text { (Rehg 1981) [21 or more] } \\
\text { (Capell 1969) [8 or more?] } \\
\text { (Dyen 1965) [24 or more?] } \\
\text { (Sohn and Bender 1973) [31] } \\
\text { (Sohn 1975) [18] }\end{array}$ \\
\hline
\end{tabular}

\section{References}

Alkire, William H. 1977. An introduction to the peoples and cultures of Micronesia. Menlo Park: Cummings.

Allan, Keith. 1977. Classifiers. Language 53:285-311.

Ambrose, W. R., J. R. Bird and P. Duerden. 1981. The impermanence of obsidian sources in Melanesia. In Archaeological studies of Pacific stone resources, ed. by F. Leach and J. Davidson, pp. 1-19. Oxford: British Archaeological Reports.

Athens, J. Stephen. 1984. Surface artefact distributions at the Nan Madol site: A preliminary assessment of spatial patterning. New Zealand Journal of Archaeology 6:129-152. . 1990a. Nan Madol pottery, Pohnpei. Micronesica Supplement 2:17-32. . 1990b. Kosrae pottery, clay, and early settlement. Micronesica Supplement 2:171-185. 


\section{Jae Jung Song}

1995. Landscape archaeology: Prehistoric settlement, subsistence, and environment of Kosrae, Eastern Caroline Islands, Micronesia. Honolulu: International Archaeological Research Institute.

Ayres, William S. 1990. Pohnpei's position in Eastern Micronesian prehistory. Micronesica Supplement 2:187-212.

and R. Mauricio. 1987. Stone adzes from Pohnpei, Micronesia. Archaeology in Oceania 22:27-31.

Bauer, Winifred. 1993. Maori. London: Routledge.

Beaumont, Clive H. 1979. The Tigak language of New Ireland. Pacific Linguistics B-58. Canberra: Australian National University.

Bellwood, P.S. 1989. The colonization of the Pacific: Some current hypotheses. In The colonization of the Pacific: A genetic trail, ed. by Adrian V.S. Hill and Susan W. Serjeantson, pp 1-59. Oxford: Clarendon Press.

Bender, Byron W. 1969. Spoken Marshallese. Honolulu : University of Hawaii Press.

1971. Micronesian languages. In Current Trends in Linguistics, vol. 8, Linguistics in Oceania, ed. by Thomas A. Sebeok, pp. 426-465. The Hague: Mouton.

1984. Object marking in Marshallese. In Studies in Micronesian linguistics, ed. by Byron W. Bender, pp. 443-465. Pacific Linguistics C-80. Canberra: Australian National University. . and Judith W. Wang. The status of Proto-Micronesian. In Austronesian linguistics at the $15^{\text {th }}$ Pacific Science Congress, ed. by Andrew Pawley and Lois Carrington, pp. 53-92. Pacific Linguistics C-88. Canberra: Australian NationalUniversity.

Best, Simon. 1987. Long distance obsidian travel and possible implications for the settlement of Fiji. Archaeology in Oceania 22:31-32.

Biggs, Bruce. 1971. The languages of Polynesia. In Current Trends in Linguistics, vol. 8, Linguistics in Oceania, ed. by Thomas A. Sebeok, pp. 466-505. The Hague: Mouton.

Blust, Robert. 1984. Malaita-Micronesian: An Eastern Oceanic subgroup? Journal of the Polynesian Society 93(2)99-140.

1985. The Austronesian homeland: A linguistic perspective. Asian Perspective26:45-67.

1995. The prehistory of the Austronesian-speaking peoples: A view from language. Journal of World Prehistory 9(4):453-510.

Buck, Peter H. (Te Rangi Hiroa). 1938. Vikings of the sunrise. New York: J. B. Lippincott.

Bugenhagen, Robert D. 1995. A grammar of Mangap-Mbula : An Austronesian language of Papua New Guinea. Canberra: Australian National University.

Capell, Arthur. 1930. The language of Inakona, Guadalcanal, Solomon Islands. Journal of the Polynesian Society 39:113-136.

. 1969. Grammar and vocabulary of the language of Sonsorol-Tobi. Sydney: University of Sydney. . 1971. Arosi grammar. Pacific Linguistics B-20. Canberra: Australian National University. , and John Layard. 1980. Materials in Atchin, Malekula: Grammar, vocabulary and texts. Pacific Linguistics D-20. Canberra: Australian National University.

Chowning, Ann. 1977. An introduction to the peoples and cultures of Melanesia. Second edition. New York: Cummings.

Churchward, C. Maxwell. 1940. Rotuman grammar and dictionary. Sydney: Methodist Church of Australasia.

Clark, Jeffrey T. and Kevin M. Kelly. 1993. Human genetics, paleoenvironments, and malaria: Relationships and implications for the settlement of Oceania. American Anthropologist 95(3): 612-630.

Comrie, B. 1993. Typology and reconstruction. In Historical linguistics: problems and perspectives, ed. by C. Jones, pp.74-97. Longman: London.

Counts, David, R. 1969. A grammar of Kaliai-Kove. Honolulu: University of Hawaii Press.

Craib, John L. 1983. Micronesian prehistory: An archaeological overview. Science 219:922-927.

Crowley, Terry. 1982. The Paamese language of Vanuatu. Pacific Linguistics B-87. Canberra: Australian National University.

1998. An Erromangan (Sye) grammar. Honolulu: University of Hawaii Press.

Davidson, Janet. 1988. Archaeology in Micronesia since 1965: Past achievements and future prospects. New Zealand Journal of Archaeology 10:83-100. 


\section{The Migration Pathway of The Proto Nuclear Micronesians: A Linguistic Trail}

Deck, Norman C. 1933-4. A grammar of the language spoken by the Kwara'ae people of Mala, British Solomon Islands. Journal of the Polynesian Society 42: 33-48, 133-44, 241-256; 43:1-16, 85-100, 163-170, 246-257.

Du Feu, Veronica. 1996. Rapanui. London: Routledge.

Dyen, Isidore. 1965. A sketch of Trukese grammar. New Haven: American Oriental Society.

Fagan, Joel L. 1986. A grammatical analysis of Mono-Alu (Bougainville Straits, Solomon Islands). Pacific Linguistics B-96. Canberra: Australian National University.

Flint, J., A. V. S. Hill, D. K. Bowden, S. J. Oppenheimer, P. R. Sill, S. W. Serjeantson, J. Bana-Koiri, K. Bhatia, M. P. Alpers, A. J. Boyce, D. J. Weatherall and J. B. Clegg. 1986. High frequencies of thalassaemia are the result of natural selection by malaria. Nature 321: 744-750.

Fox, G. J. 1979. Big Nambas grammar. Pacific Linguistics B-60. Canberra: Australian National University. Grace, George W. 1955. Subgrouping of Malayo-Polynesian: A report of tentative findings. American Anthropologist 57(2):337-339.

1961. Austronesian linguistics and culture history. American Anthropologist 63:359-368.

1964. The linguistic evidence. Current Anthropology 5:361-368.

Green, R. C. 1976a. Languages of the Southeast Solomons and their historical relationships. In Southeast Solomon Islands culture history, ed. by R. C. Green and M. M. Cresswell, pp. 47-60. Royal Society of New Zealand Bulletin No. 11.

1976b. Lapita sites in the Santa Cruz Group. In Southeast Solomon Islands culture history, ed. by

R. C. Green and M. M. Cresswell, pp. 245-265. Royal Society of New Zealand Bulletin No. 11. 1979. Lapita. In The prehistory of Polynesia, ed. by Jesse D. Jennings, pp. 27-60. Canberra: Australian National University Press.

1981. Location of the Polynesian homeland: A continuing problem. In Studies in Pacific languages and cultures in honour of Bruce Biggs, ed. by J. Hollyman and A. Pawley, pp. 133-158. Auckland: Linguistic Society of New Zealand.

1991. A reappraisal of the dating for some Lapita sites in the Reefs/Santa Cruz Group of the southeast Solomons. Journal of the Polynesian Society 100:197-207.

Greenberg, J.H. (1957) The nature and uses of linguistic typologies. International Journal of American Linguistics 23:68-77.

1995. The diachronic typological approach to language. In Approaches to language typology, ed. by M. Shibatani and T. Bynon, pp. 145-166. Oxford: Clarendon Press.

Groves, Terab'ata R., Gordon W. Groves and Roderick Jacobs. 1985. Kiribatese: An outline description. Pacific Linguistics D-64. Canberra: Australian National University.

Guy, Jaques B.M. 1974. A grammar of the northern dialect of Sakao. Pacific Linguistics B-33. Canberra: Australian National University.

Haider, H. 1985. The fallacy of typology. Lingua 65: 1-27.

Harrison, Sheldon P. 1976. Mokilese reference grammar. Hawaii: University Press of Hawaii. . 1988. A plausible history for Micronesian possessive classifiers. Oceanic Linguistics 27:63-78.

Hawkins, J.A. 1979. Implicational universals as predictors of word order change. Language 55: 618-648. 1980. On implicational and distributional universals of word order. $J L$ 16: 193-235.

. 1983. Word order universals. Academic Press: New York.

Higgs, D. R., M. A. Vickers, A. O. M. Wilkie, I.-M. Pretorius, A. P. Jarman and D. J. Weatherall. 1989. A review of the molecular genetics of the human $\alpha$-globin gene cluster. Blood 73:1081-1104.

Hill, A. V. S., D. F. O'Shaughnessy and J. B. Clegg 1989. Haemoglobin and globin gene variants in the Pacific. In The colonization of the Pacific: A genetic trail, ed. By Adrian V.S. Hill and Susan W. Serjeantson, pp 246-285. Oxford: Clarendon Press.

Hill, Adrian V.S. and Susan W. Serjeantson, eds. 1989. The colonization of the Pacific: A genetic trail. Oxford: Clarendon Press.

Holzknecht, Susanne. 1986. A morphology and grammar of Adzera (Amari dialect), Morobe Province, Papua New Guinea. Papers in New Guinea Linguistics 24:77-166. Pacific Linguistics A-70.

Howells, William. 1973. The Pacific Islanders. Wellington: A. H. and A. W. Reed. 


\section{Jae Jung Song}

Intoh, Michiko. 1996. Cultural contacts between Micronesia and Melanesia. Paper presented at The Western Pacific, 5000 to 2000 BP: Colonisations and transformations, Port Vila, Vanuatu, July 31August 6, 1996.

1997. Human dispersals into Micronesia. Anthropological Science 105(1):15-28.

Irwin, Geoffrey. 1992. The prehistoric exploration and colonisation of the Pacific. Cambridge: Cambridge University Press.

Ivens, Walter G. 1913-4. Grammar of the language of Ulawa, Solomon Islands. Journal of the Polynesian Society 22:28-35, 96-103, 134-140, 219-224; 23:21-27.

1926-28. A study of the Oroha language, Mala, Solomon Islands. Bulletin of the School of Oriental and African Studies 4:587-610.

. 1933. A grammar of the language of Bugotu, Ysabel Island, Solomon Islands. Bulletin of the School of Oriental and African Studies 7:141-177. 1934a. A grammar of the language of Longgu, Guadalcanal, British Solomon Islands. Bulletin of the School of Oriental and African Studies 7:601-621.

1934b. A grammar of the language of Vaturanga, Guadalcanal, British Solomon Islands. Bulletin of the School of Oriental and African Studies 7:349-375.

Jackson, Frederick H. 1986. On determining the external relationships of the Micronesian languages. In FOCAL II: Papers from the Fourth International conference on Austronesian linguistics, ed. by Paul Geraghty, Lois Carrington and S. A. Wurm, pp. 201-238. Pacific Linguistics C-94. Canberra: Australian National University.

Jakobson, R. 1958. Typological studies and their contribution to historical and comparative linguistics. In Proceedings of the Eighth International Congress of Linguists, pp. 17-25. Oslo University Press: Oslo.

Johnston, Raymond L. 1980. Nakanai of New Britain: The grammar of an Oceanic language. Pacific Linguistics B-70. Canberra: Australian National University.

Keesing, Roger M. 1985. Kwaio grammar. Pacific Linguistics B-88. Canberra: Australian National University.

Kennedy, J. 1982. Archaeology in the Admiralty Islands: some excursions. Bulletin of the Indo-Pacific Prehistory Association 3:22-35.

Kirch, P. V. 1983. An archaeological exploration of Vanikoro, Santa Cruz Islands, eastern Melanesia. New Zealand Journal of Archaeology 5:69-113.

Kirch, Patrick Vinton. 1997. The Lapita peoples: Ancestors of the Oceanic world. Oxford: Blackwell.

Kolia, J. A. 1975. A Balawaia grammar sketch and vocabulary. In Studies in languages of central and south-east Papua, ed. by T. E. Dutton, pp. 107-226. Pacific Linguistics C-29. Canberra: Australian National University.

Lanyon-Orgill, P. A. 1945. Grammar of the Pokau language, Central Division of Papua New Guinea. Bulletin of the School of Oriental and African Studies 11:641-655.

Lee, Kee-dong. 1975. Kusaiean reference grammar. Honolulu: University Press of Hawaii.

Lewis, David. 1994. We, the navigators: The ancient art of landfinding in the Pacific. Second edition. Honolulu: University of Hawaii Press.

Lichtenberk, Frantisek. 1978. A sketch of Houailou grammar. University of Hawai'I Working Papers in Linguistics 10.2:74-116.

1983a. Relational classifiers. Lingua 60:147-176.

1983b. A grammar of Manam. Honolulu: University of Hawaii Press.

1984. To'aba'ita language of Malaita, Solomon Islands. Working Papers in Anthropology, Archaeology, Linguistics, and Maori Studies, No. 65. Department of Anthropology, University of Auckland.

1985. Possessive constructions in Oceanic languages and in Proto-Oceanic. In Austronesian Linguistics at the $15^{\text {th }}$ Pacific Science Congress, ed. by Andrew Pawley and Lois Carrington, pp. 93-140. Pacific Linguistics C-88. Canberra: Australian National University. 1986. Syntactic-category change in Oceanic languages. Oceanic Linguistics 24:1-84.

Lincoln, Peter C. 1976. Describing Banoni, an Austronesian language of Southwest Bougainville. Unpublished Ph.D. dissertation, University of Hawai'i. 
The Migration Pathway of The Proto Nuclear Micronesians: A Linguistic Trail

1978. Reefs-Santa Cruz as Austronesian. In Second International Conference on Austronesian Linguistics: Proceedings, ed. by Stephen A. Wurm and Lois Carrington, pp. 929-967. Pacific Linguistics C-61. Canberra: Australian National University.

Lynch, John. 1973. Verbal aspects of possession in Melanesian languages. Oceanic Linguistics 12:69-102. . 1978. A grammar of Lenakel. Pacific Linguistics B-55. Canberra: Australian National University. A-64. 1982. Anejom grammar sketch. Papers in Linguistics of Melanesia 4:93-154. Pacific Linguistics

1998. Pacific languages: An introduction. Honolulu: University of Hawai'I Press.

and Darrell T. Tryon. 1985. Central-Eastern Oceanic: A subgrouping hypothesis. In Austronesian Linguistics at the $15^{\text {th }}$ Pacific Science Congress, ed. by Andrew Pawley and Lois Carrington, pp. 31-52. Pacific Linguistics C-88. Canberra: Australian National University.

Marck, Jeffrey C. 1975. The origin and dispersal of the Proto Nuclear Micronesians. Unpublished M.A. thesis, University of Iowa.

1986. Micronesian dialects and the overnight voyage. Journal of the Polynesian Society 95:253-258

. n.d. Towards a multiple working hypothesis approach to problems in nuclear Micronesian settlement. MS.

McCoy, Patrick C. and Paul L. Cleghorn. 1988. Archaeological excavations on Santa Cruz (Nendö), southeast Solomon Islands: Summary report. Archaeology in Oceania 23:104-115.

Melton, Terry, Stephanie Clifford, Jeremy Martinson, Mark Batzer and Mark Stoneking. 1998. Genetic evidence for the Proto-Austronesian homeland in Asia: mtDNA and nuclear DNA variation in Taiwanese aboriginal tribes. American Journal of Human Genetics 63: 1807-1823.

Milner, G. B. 1972. Fijian grammar. Suva: Government Press.

Mosel, Ulrike. 1984. Tolai syntax and its historical development. Pacific Linguistics B-92. Canberra: Australian National University.

and Even Hovdhaugen. 1992. Samoan reference grammar. Oslo: Scandinavian University Press.

Nichols, Johanna. 1992. Linguistic diversity in space and time. Chicago: University of Chicago Press.

O'Shaughnessy, D. F., A. V. S. Hill, D. K. Bowden, D. J. Weatherall and J. B. Clegg. 1990. Globin genes in Micronesia: Origins and affinities of Pacific Island Peoples. American Journal of Human Genetics 46:144-155.

Osumi, Midori 1995. Tinrin grammar. Honolulu: University of Hawaii Press.

Paton, W. F. 1971. Ambrym (Lonwolwol) grammar. Pacific Linguistics B-19. Canberra: Australian National University.

Pawley, Andrew. 1972. On the internal relationships of Eastern Oceanic languages. In Studies in Oceanic culture history, vol. 3, ed. by R. C. Green and M. Kelly, pp. 1-142. Honolulu: Bernice P. Bishop Museum.

1973. Some problems in Proto-Oceanic grammar. Oceanic Linguistics 12:103-188.

. 1977. On redefining "Eastern Oceanic". MS.

1979. New evidence on the position of Rotuman. Working Papers in Anthropology, Archaeology, Linguistics, and Maori Studies, No. 56. Department of Anthropology, University of Auckland.

1981. Melanesian diversity and Polynesian homogeneity: A unified explanation for language. In Studies in Pacific languages and cultures in honour of Bruce Biggs, ed. by J. Hollyman and A. Pawley, pp. 269-309. Auckland: Linguistic Society of New Zealand.

and Roger Green. 1984. The Proto-Oceanic language community. The Journal of Pacific History 19:123-146.

and _ 1973. Dating the dispersal of the Oceanic languages. Oceanic Linguistics 12:1-67.

and Malcolm Ross. 1993. Austronesian historical linguistics and culture history. Annual Review of Anthropology 22:425-459.

and 1995. The prehistory of the Oceanic languages: A current view. In The Austronesians, ed. by Peter Bellwood, James J. Fox and Darrell Tryon, pp. 39-74. Canberra: Department of Anthropology, Australian National University.

Rehg, Kenneth L. 1981. Ponapean reference grammar. Honolulu: University Press of Hawaii. 


\section{Jae Jung Song}

1995. The significance of linguistic interaction spheres in reconstructing Micronesian prehistory. Oceanic Linguistics 34:305-325.

Ross, M. D. 1988. Proto Oceanic and the Austronesian languages of Western Melanesia. Pacific Linguistics C-98. Canberra: Australian National University.

Schütz, Albert J. 1969. Nguna grammar. Honolulu: University of Hawaii Press.

Seiter, William. 1980. Studies in Niuean syntax. New York: Garland.

Serjeantson, S. W. 1989. HLA genes and antigens. In The colonization of the Pacific A genetic trail, ed. by Adrian V.S. Hill and Susan W. Serjeantson, pp 120-173. Oxford: Clarendon Press.

Serjeantson, S. W., and A. V. S. Hill. 1989. The colonization of the Pacific: The genetic evidence. In The colonization of the Pacific: A genetic trail, ed. by Adrian V.S. Hill and Susan W. Serjeantson, pp 286-294. Oxford: Clarendon Press.

Serjeantson, S. W., R. L. Kirk, and P. B. Booth. 1983. Linguistic and genetic differentiation in New Guinea. Journal of Human Evolution 12: 77-92.

Shutler, Richard and Jeffrey C. Marck. 1975. On the dispersal of the Austronesian horticulturalists. Archaeology and Physical Anthropology in Oceania 10(2):81-113.

Siegel, Jeff. 1984. Introduction to the Labu language. Papers in New Guinea Linguistics 23:83-157. Pacific Linguistics A-69. Canberra: Australian National University.

Smythe, W. E. 1970. Melanesian, Micronesian, and Indonesian features in languages of the Admiralty Islands. In Pacific linguistic studies in honour of Arthur Capell, ed. by S. A. Wurm and D. C. Laycock, pp. 1209-1234. Pacific Linguistics C-13. Canberra: Australian National University.

Sohn, Ho-Min. 1975. Woleaian reference grammar. Honolulu: University Press of Hawaii. and Byron W. Bender. 1973. A Ulithian grammar. Pacific Linguistics C-27. Canberra: Australian National University.

Song, Jae Jung. 1997. The history of Micronesian possessive classifiers and benefactive marking in Oceanic languages. Oceanic Linguistics 36(1):29:64.

2001. Linguistic typology: Morphology and syntax. Harlow and New York: Longman (Pearson Education).

Sperlich, Wolfgang B. 1991. Namakir: A description of a central Vanuatu language. Unpublished Ph.D. thesis, University of Auckland.

Spriggs, Matthew. 1984. The Lapita cultural complex: Origins, distribution, contemporaries and successors. The Journal of Pacific History 19(3-4):202-223.

1995. The Lapita culture and Austronesian prehistory in Oceania. In The Austronesians, ed. by Peter Bellwood, James J. Fox and Darrell Tryon, pp. 112-133. Canberra: Department of Anthropology, Australian National University.

1996. Chronology and colonisation in island Southeast Asia and the Pacific: New data and an evaluation. In Oceanic culture history: Essays in honour of Roger Green, ed. by J. M. Davidson, G. Irwin, B. F. Leach, A. Pawley and D. Brown, pp. 33-50. Dunedin: New Zealand Journal of Archaeology Special Publication.

1997. Island Melanesians. Oxford: Blackwell.

Takayama, Jun. 1981. Early pottery and population movements in Micronesian prehistory. Asian Perspectives 24 (1):1-10.

Terrell, John. 1986. Prehistory in the Pacific Islands: a study of variation in language, customs and human biology. Cambridge: Cambridge University Press.

Todd, Evelyn M. 1978. A sketch of Nissan (Nehan grammar). In Second International Conference on Austronesian Linguistics: Proceedings, ed. by S. A. Wurm and Lois Carrington, pp. 1181-1239. Pacific Linguistics C-61. Canberra: Australian National University.

Tryon, D. T. 1967. Nengone grammar. Pacific Linguistics B-6. Canberra: Australian National University. 1968a. Dehu grammar. Pacific Linguistics B-7. Canberra: Australian National University. 1968b. Iai grammar. Pacific Linguistics B-8. Canberra: Australian National University. 1984. The peopling of the Pacific: A linguistic appraisal. The Journal of Pacific History 19:147-159. 
The Migration Pathway of The Proto Nuclear Micronesians: A Linguistic Trail

1994. Language contact and contact-induced language change in the Eastern Outer Islands, Solomon Islands. In Language contact and change in the Austronesian world, ed. by Tom Dutton and Darrell T. Tryon, pp. 611-648. Berlin: Mouton de Gruyter.

Walsh, David S. 1966. The phonology and phrase structure of Raxa. Unpublished M.A. thesis, University of Auckland.

White, J. P., J. Allen, and J. Specht. 1988. Peopling the Pacific: the Lapita Homeland Project. Australian Natural History 22:410-416.

Wilson, William H. 1982. Proto-Polynesian possessive marking. Pacific Linguistics B-85. Canberra: Australian National University.

Wivel, Richard. 1981. Kairiru grammar. Unpublished M.A. thesis, University of Auckland.

Wurm, Stephen A. 1967. Linguistics and the prehistory of the South-western Pacific. Journal of Pacific History 2:25-38.

1969. The linguistic situation in the Reef and Santa Cruz Islands. PacificLinguistics A 21:47-105.

1970. Austronesian and the vocabulary of languages of the Reef and Santa Cruz Islands -A preliminary approach. In Pacific linguistic studies in honour of Arthur Capell, ed. by S. A. Wurm and D. C. Laycock, pp. 467-553. Pacific Linguistics C-13. Canberra: Australian National University.

1972. Notes on the indication of possession with nouns in Reefs and Santa Cruz Islands languages. Papers in Linguistics of Melanesia 3:85-113. Pacific Linguistics A-35.

. 1976. The Reef Islands-Santa Cruz family. In New Guinea area languages and language study, Vol. 2, Austronesian languages, ed. by S. A. Wurm, pp. 637-674. Pacific Linguistics C-39. Canberra: Australian National University.

1978. Reefs-Santa Cruz: Austronesian, but..! In Second International Conference on Austronesian Linguistics: Proceedings, ed. by Stephen A. Wurm and Lois Carrington, pp. 969-1010. Pacific Linguistics C-61. Canberra: Australian National University.

Zewen, François X.N. 1977. The Marshallese language: A study of its phonology, morphology and syntax. Berlin: Dietrich Reimer. 